NBER WORKING PAPER SERIES

\title{
ENDOGENOUS DISCOUNTING, THE WORLD SAVING GLUT AND THE U.S. CURRENT ACCOUNT
}

\author{
Horag Choi \\ Nelson C. Mark \\ Donggyu Sul \\ Working Paper 13571 \\ http://www.nber.org/papers/w13571
}

\author{
NATIONAL BUREAU OF ECONOMIC RESEARCH \\ 1050 Massachusetts Avenue \\ Cambridge, MA 02138 \\ November 2007
}

We have benefitted from the comments by seminar participants at Brandeis University, City University of Hong Kong, the Dallas Fed, the University of Kentucky, the Philadelphia Fed and the St. Louis Fed. The comments of two anonymous referees and Charles Engel (the editor) led to a substantially revised and improved paper. Mark thanks the NSF for support. The views expressed herein are those of the author(s) and do not necessarily reflect the views of the National Bureau of Economic Research.

(C) 2007 by Horag Choi, Nelson C. Mark, and Donggyu Sul. All rights reserved. Short sections of text, not to exceed two paragraphs, may be quoted without explicit permission provided that full credit, including () notice, is given to the source. 
Endogenous Discounting, the World Saving Glut and the U.S. Current Account

Horag Choi, Nelson C. Mark, and Donggyu Sul

NBER Working Paper No. 13571

November 2007

JEL No. F32,F41

\section{ABSTRACT}

We study the evolution of the U.S. current account in a two-country dynamic stochastic endowment model in which a single non-state contingent bond is the only internationally traded asset. The paper focuses on the world 'saving glut' as the primary cause of continual deterioration in the current account and departs from the standard framework by introducing a three-parameter model of the subjective discount factor that depends on societal (per capita) variables that are external to household choices. When agents in the model are presented with U.S. and rest-of-world endowment data as the realization of the exogenous state vector, endogenously driven short-run international differences in subjective discounting that display increasing relative U.S. impatience create saving and current account imbalances that matches patterns observed in the data.

Horag Choi

Department of Economics

University of Auckland

h.choi@auckland.ac.nz

Nelson C. Mark

Department of Economics and Econometrics

University of Notre Dame

Notre Dame, IN 46556

and NBER

nmark@nd.edu
Donggyu Sul

Department of Economics

University of Auckland

d.sul@auckland.ac.nz 


\section{Introduction}

Over the past 30 years, the U.S. current account has more or less been on a trajectory of a sustained deterioration A substantial and protracted decline since 1991 has drawn attention and concern from policy makers and researchers alike. ${ }^{1}$ The objective of this paper is to model and to understand the primary determinants of the U.S. current account since 1975. While there are at least as many explanations of the current account as there are components in its construction, $S-I+(T-G)$, this paper focuses on the saving channel $S$.

We work with a two-country dynamic stochastic endowment model in which a single nonstate contingent bond is the only internationally traded asset. By allowing incomplete asset markets, temporary international reallocations of wealth and associated current account imbalances can occur. Our point of departure from the standard framework is a three-parameter model of the subjective discount factor that depends on societal (per capita) variables that are external to household choices. This allows short-run equilibrium differences in U.S. and rest-of-world (ROW) impatience to arise endogenously while requiring that those differences vanish in the steady state so a permanently patient country does not end up owning the world's wealth. As in Engel and Rogers (2006), our paper seeks to quantitatively assess the ability of a simple but rational model to explain the time-path of the data in the following sense: If agents in the model are presented with the data as realizations of the exogenous state vector, how well do equilibrium consumption choices of people in the model explain the realized path of the current account data? We find that the choices generated by this exercise produce relatively high U.S. consumption, a ROW saving glut and an associated U.S. current account deficit that explains the historical experience better than the standard model with fixed discount factors (FDF). While we are not arguing that the saving imbalance tells the whole story about the current account, a compelling case can be made for concentrating on the saving imbalance if one wants to focus on what is quantitatively the most important factor driving the deficit. Our strategy is to take this approach and to push as hard as we can on this channel to see what it does explain.

Looking over a three-decade period of data, the very obvious negative trend in the current account has been accompanied by U.S. GDP growth that has outstripped growth in the ROW, and a relatively low U.S. saving rate. The discrepancy between ROW and U.S. saving rates

\footnotetext{
${ }^{1}$ Recent research includes Nason and Rogers (2006) who attempt to identify the source of deviations between the data and a standard small-open economy real business cycle model, Bergin (2006) who attempts to fit a new-open economy macro model to the data, Bergin and Sheffrin (2000) and Gourinchas and Rey (2005) who examine present value implications for the current account, Blanchard et al. (2005) who model the exchange rate and current account in a portfolio balance framework, Edwards (2005) and Obstfeld and Rogoff (2004), estimate the exchange rate impact of unwinding the current account deficit.
} 
has been reported by Dooley et al. (2005) to be as large as 10 percent and the gap between U.S. and ROW saving rates has increased over time with ROW saving rates rising slightly and U.S. rates falling over time.

We take as our benchmark, the standard model with FDF. This is a slight generalization of the Engel-Rogers (2006) 'shares' model. ${ }^{2}$ The difficulty confronting the FDF model is, conditional on the history of a rising relative U.S. endowment, it predicts that the current account should have steadily improved over the sample period being studied which is the opposite of what is observed in the data. This is because in the FDF model, a positive endowment shock induces consumption smoothing agents to increase their lending to foreigners which improves the current account. To the extent that an evolving saving rate plays a role in current account determination, the FDF model will struggle since it implies a stationary saving rate.

Thus, in working with an endogenous discount factor (EDF), we join an international economics literature in which EDFs have figured prominently at least since Obstfeld (1982) applied the Uzawa specification to analyze a small-open economy's response to terms of trade shocks. In our setup, people become increasingly impatient when societal (per capita) consumption rises above its natural or steady-state value. As relative impatience rises, net foreign assets fall and the current account deteriorates. Conversely, when societal consumption falls below the steady state value, impatience declines, net foreign assets rise and the current account improves. Qualitatively, consumption/saving decisions of agents in our model resemble bufferstock saving studied by Carroll (1997, 2001, 2004). However, instead of adjusting saving to achieve a target value of wealth, our agents adjust to achieve a target level of consumption which is given by the steady state value.

Other research in international economics that has incorporated EDFs include Mendoza (1991) and Schmitt-Grohe (1998) who study small-open economy real business cycle models. These papers were primarily concerned with the ability of the models to match selected moments of the data and were not geared towards understanding their actual time-paths. The primary role of endogenous discounting in those papers is to induce stationary steady state levels of debt when markets are incomplete and those authors chose parameterizations that created only small departures from the standard model. In contrast, our motivation for incorporating endogenous discounting is to model a changing saving rate and we are particularly interested in exploring more substantial departures from the standard model precisely because the FDF model generates counterfactual implications with respect to the U.S. current account experience. ${ }^{3}$

\footnotetext{
${ }^{2}$ The Engel-Rogers model is the perfect foresight version of the standard model under log utility.

${ }^{3}$ Ghironi et al. (2005) studies the current account in an overlapping generations model with exogenously
} 
Our paper does not investigate whether the present current account deficit is sustainable. ${ }^{4}$ Because the EDF model has a stationary steady state, the only sustainable current account is the imbalance given by the initial conditions. Starting from a position of zero net indebtedness, the model predicts that a turnaround in a current account deficit must eventually occur. However, we can ask the model to give us a projected time frame for unwinding the deficit. Starting from a deficit of $5.7 \%$ of GDP (the 2004 value), we project the current account forward assuming that future innovations to the exogenous state vector are zero. Without help from relatively higher growth in the ROW endowment, the current account is not projected to be balanced until 2030 .

The remainder of the paper is as follows. The next section presents the external balance data that we seek to understand and surveys some popular explanations of the current account. It then conducts a coarse examination of the aggregate data which motivates and supports our strategy of emphasizing the role of the saving imbalance at the expense of alternative channels of influence. Section 3 presents the two-country endowment model that is the workhorse for our quantitative work. Section 4 reports our main assessment of the model through an examination of the model's current account predictions implied by agent choices when they are presented with the historical data as the exogenous state vector. It also generates current account projections arising from an unwinding of the deficit. Section 5 concludes. The appendix describes the data and contains some details about the model.

\section{The U.S. current account deficit and primary causes}

The annual U.S. current account data that we seek to understand (along with the trade account) are shown in Figure 1. Two conspicuous features of the current account command our attention. The first is the steady and sustained downward trend spanning over the entire 30 year sample. Evidently, the recent worsening of the current account is a continuation of a longer run phenomenon. The second feature are cyclical fluctuations or short-run trend reversals. The current account, which was roughly in balance through the late 1970s, underwent a large and sustained deterioration in the first half of the 1980s which was reversed in 1986 and reversed again in 1991. Since 1991, the current account has trended downwards reaching a deficit of $6.4 \%$ of GDP in 2005.

Next, we review some popular explanations of the current account that have been discussed

given international differences in subjective discount factors. The absense of intergenerational bequests prevents the patient country from owning the world's wealth in the steady state.

${ }^{4}$ Consequently, we do not ask whether a particular current account deficit is sustainable. Mann (1999), Obstfeld and Rogoff (2004), and Faruqee et al. (2005) ask whether the current account is sustainable. 
in the literature. We argue that a rough assessment of the explanatory power of these alternative explanations suggests that placing primary importance on relative saving imbalances is not a silly thing to do.

\subsection{Potential channels of influence}

The twin deficits hypothesis. This idea starts with the national income account identity that equates the current account with the excess of saving over investment plus the fiscal surplus. If agents are non Ricardian, then an increase in the fiscal deficit that is incompletely offset by an increase in private saving will worsen the current account. Despite the simplicity of the argument, empirical studies have uncovered little evidence that budget deficits are a quantitatively important source of current account movements. Papers that do find the fiscal balance to be somewhat important are Chinn and Prasad (2003) who obtain an estimated coefficient of 0.375 , meaning that a 1 percent increase in the fiscal deficit is associated with a 0.375 percent increase in the current account deficit, and Chinn and Ito (2005) who obtain a coefficient of $0.21 .^{5}$ On the other hand, Corsetti and Müller (2006) find no evidence that a reduction in the U.S. fiscal deficit will have any effect on the current account, Bussière et al. (2005) obtain an estimated fiscal balance coefficient of 0.07 for G-7 current accounts while Gruber and Kamin (2005) estimate the fiscal balance coefficient to be only 0.09 .

Investment imbalance. A second explanation is that the current account deficit has been driven by a U.S. investment boom combined with a shortage of attractive investment opportunities in the ROW. An example that comes to mind is how Japan's zero-interest rate policy failed to stimulate meaningful investment in Japan at the same time that Japanese automobile manufacturers undertook direct investment projects in the U.S. Potential factors that may contribute to the creation of relatively attractive U.S. investment opportunities include (1) high relative U.S. productivity growth and the associated increase in the U.S. share of world income, (2) the high relatively quality of U.S. institutions, (3) the superior depth and development of U.S. financial markets.

Rising U.S. share of world income. Engel and Rogers (2006) identify the rising U.S. share of world income as a critical factor in the saving context. They develop a model where the current account can be represented approximately as the expected present value of the future share of U.S. to ROW income. The permanent income consumers who populate their model increase current consumption in response to an increase in the expected future U.S. share. They argue

\footnotetext{
${ }^{5}$ These refer to slope coefficients on the fiscal balance divided by GDP in regressions where the dependent variable is the current account divided by GDP.
} 
that if the surge in the U.S. share was anticipated, then the current account would deteriorate as people increase current spending out of higher future income. However, it is difficult to parametrically model the relative income process in such a way that a sustained increase is anticipated years in advance so they were unable to generate such behavior in their model.

Saving rate imbalance. This explanation says that the current account is the result of a ROW saving glut combined with a low U.S. saving rate. The discrepancy in saving is especially noticeable when comparing to east-Asian households where saving rates have long exceeded those in the U.S. Recently, these already high foreign saving rates surged upwards in the aftermath of the 1997 Asian financial crisis. Bernanke (2005) attributes this to the precautionary saving motive arising primarily from East Asian countries such as Korea, Thailand, and China, who have built up foreign exchange reserves to guard against instability in capital flows and exchange rates. On the U.S. side, the low saving rate is well known. The U.S. saving rate has trended downwards since at least the 1970s. For example, Bosworth et al. (1991) report that household discretionary saving in the U.S. declined from 5.1 percent in the 1970 s to 2.2 percent in the 1980s.

\subsection{Explanatory power of alternative channels}

Presumably, each of the factors mentioned above play some role in determining the current account. However, we are interested in building a small dynamic stochastic general equilibrium model that focuses on the primary channels of influence. The empirical analysis in this subsection attempts to narrow down the list of primary channels.

Table 1: Determinants of the current account deficit

\begin{tabular}{c|ccccc|cccc}
\hline \hline & \multicolumn{5}{|c|}{ No trend } & \multicolumn{5}{c}{ With trend } \\
\hline$a_{0}$ & $\mathbf{- 1 5 . 7 7}$ & $\mathbf{- 8 . 8 5 7}$ & $\mathbf{- 8 . 0 3 4}$ & 4.789 & $\mathbf{- 8 . 8 8 7}$ & $\mathbf{- 1 5 . 3 4}$ & $\mathbf{- 1 1 . 1 6}$ & $\mathbf{- 5 . 1 6 2}$ & -5.003 \\
$a_{1}$ & & & & & & -0.005 & 0.045 & $\mathbf{- 0 . 0 6 4}$ & $\mathbf{- 0 . 1 8 2}$ \\
\hline$\tilde{y}$ & $\mathbf{- 2 8 . 0 2}$ & & & & & $\mathbf{- 2 7 . 3 0}$ & & & \\
$\tilde{c}$ & & $\mathbf{- 2 0 . 7 4}$ & & & $\mathbf{- 2 0 . 1 7}$ & & $\mathbf{- 2 5 . 6 5}$ & & \\
$\tilde{x}$ & & & $\mathbf{- 7 . 1 1 0}$ & & -0.253 & & & $\mathbf{- 4 . 8 7 2}$ & \\
$\tilde{g}$ & & & & 11.367 & & & & & -10.03 \\
$\overline{\mathrm{R}}^{2}$ & 0.749 & 0.799 & 0.609 & 0.118 & 0.791 & 0.740 & 0.805 & 0.658 & 0.561 \\
\hline \hline
\end{tabular}

Note: Bold face indicates significance at the 5 percent level 
We begin with a regression analysis of the current account to GDP ratio, ca. To capture aspects government policies, we include $\tilde{g}$, the log ratio of U.S. to ROW of government spending on final goods. To assess the role of an investment imbalance, we include $\tilde{x}$, the log ratio of U.S. to ROW investment. To address the role of the U.S. income ratio we include $\tilde{y}$, the log ratio of U.S. to ROW GDP, and to investigate the role of the world saving glut, we include $\tilde{c}$, the log ratio of U.S. to ROW consumption. The ROW is comprised of 23 high income OECD countries whose 2005 per capita gross national income exceeded $\$ 10,726$. The data are more fully described in the appendix.

Table 1 reports results of estimating variants of the regression

$$
c a=a_{0}+a_{1} t+b_{1} \tilde{y}+b_{2} \tilde{c}+b_{3} \tilde{x}+b_{4} \tilde{g}+\text { error }
$$

where $t$ is a time trend. Government spending ratios are insignificant in simple regressions that include a constant but no trend. Although we don't have tax data in the analysis, the insignificance of $\tilde{g}$ is consistent with more careful empirical work from the literature that finds the fiscal balance to be a quantitatively unimportant determinant of the current account.

In separate regressions, the GDP ratio $\tilde{y}$, the consumption ratio $\tilde{c}$, and the investment ratio $\tilde{x}$, are individually significant. The signs on the estimated coefficients are negative suggesting that an increase in the relative U.S. value of any of these variables is associated with a worsening of the current account. Support for the investment imbalance hypothesis is fragile, however. When $\tilde{c}$ and $\tilde{x}$ are both included in the regression, the coefficient on the investment variable is insignificant and the $\bar{R}^{2}$ is lower than it is in the regression of $c a$ on $\tilde{c}$ only.

The observations are highly persistent and probably contain a unit root. This raises the possibility that the significance reported above is an artifact of the spurious regression problem (Granger and Newbold (1974)). To address this issue, we employ Park's (1990) variable addition test for cointegration. The variable that we add is a time trend. If the preceding regressions are spurious, then adding a time trend to the regression will yield significant estimates of the time-trend coefficient $a_{1}$. If, on the other hand, the observations are co-integrated unit-root processes, then the time-trend coefficient will be insignificant.

When we add the trend, evidence continues to mount against fiscal and investment factors as the time-trend coefficients are significant in these regressions. The evidence continues to support the saving imbalance as the primary determinant of the current account as the timetrend coefficients are insignificant in the $\tilde{c}$ and $\tilde{y}$ regressions while the slope coefficients on $\tilde{c}$ and on $\tilde{y}$ remain significant.

To summarize, the regression analysis consistently points to consumption/saving behavior as the primary driver of the current account. Since we have not employed tax data, we cannot claim to have done a careful analysis of the twin-deficits hypothesis. However, given 
the unimportance of government spending in conjunction with the literature's underwhelming empirical support we are comfortable in abstracting away from the fiscal balance. ${ }^{6}$

\subsection{A closer look at the saving imbalance}

There is no unique definition of the saving rate. Two definitions that have been employed are the net national saving rate $(Y-C-G) / Y$, and the private sector saving rate $(Y-C-$ $G) /(Y-G)$. A third is a crude measure of household saving $S / Y=1-(C / Y)$. Since we are primarily interested in household saving behavior and because the broad trends in all of these series are quite similar, it will suffice for our purposes to examine the behavior of $1-(C / Y)$.

Figure 2 displays the HP trends of U.S. and ROW saving rates. ${ }^{7}$ The ROW saving rate appears to surge in the late 1990s, perhaps due to the increased precautionary saving stressed by Bernanke. Over the full sample, ROW saving is observed to have trended up modestly while the U.S. rate has more noticeably trended down. Our crude measure of the ROW saving rate measured 41 percent in 1975 and increased to 42.5 percent in 2001. The U.S. saving rate went as high as 34.9 percent in 1981 fell to 28.7 percent in 2003. The difference between the 0.02 percent per year increase in the ROW rate and the -0.12 percent per year decline in the U.S. rate is statistically significant $(t=-8.0)$.

Figure 3 plots the current account, the log ratio of ROW to U.S. GDP and the log ratio of U.S. to ROW saving rates. These observations have been standardized to promote visual comparison among the series. Here, it can be see that U.S. GDP growth has outstripped GDP growth in ROW. The value of ROW to U.S. GDP which stood at 1.75 in 1975 declined to 1.49 by 2003. The relative income series, the relative saving rate series and the current account all display an overall downward trend with similar cyclical fluctuations around that trend.

The model that we develop below is driven by the evolution of country endowment, which we construct as $Y-I-G$. Since an increase in investment or government consumption impact negatively on the endowment, a question thus arises about how heavily these variables influence the endowment. Figure 4 plots the ratio of ROW to U.S. GDP and the ratio of U.S. to ROW endowment. As can be seen, the relative endowment series displays more cyclical variability in the 1970s whereas relative GDP appears more cyclical from the 1980s onward.

\footnotetext{
${ }^{6}$ We note that there are many other potential explanations for current account raised in the literature that we have not addressed. Among these include the exorbitant privilege - the higher returns earned by U.S. investors on foreign assets than returns earned by foreign holders of U.S. assets (Gourinchas and Rey [2005]) — that has helped the U.S. to finance the deficits, demographic factors (Domeij and Floden [2006]), and the U.S provision of collateral to poor countries that enables capital formation to be financed through U.S. financial markets (Dooley et al. [2004]). Analyses of these ideas are beyond the scope of the present paper.

${ }^{7}$ The parameter value of 6.25 is used in the HP filtering.
} 
While the cyclical aspects are altered somewhat by movements in investment and government consumption, the overall trend of the two series are quite similar. The similarity between the relative endowment and GDP trends is consistent with the regression analysis presented earlier which found investment and government consumption to have had limited impact in driving the current account.

The downward trend in the income-consumption ratios is a problem for the standard model since it implies that the consumption-income ratio is stationary. But it would be wrong to say that the puzzle is due entirely to the restrictiveness of the representative agent framework. A look at empirical micro studies on saving behavior of heterogeneous agents finds no consensus on the underlying source of the decline in the U.S. saving rate. While Attanasio (1998) argues that those born between 1925 and 1939 are responsible for the decline, Summers et al. (1987) and Boswoth et al. (1991) reject the hypothesis that the decline can be traced to specific age cohorts (e.g., the baby boom generation) or the changing composition of traditionally high savers (married couples) and low savers (the young and retirees). Gokhale et al. (1996) argue that the decline can be partially attributed to the expansion of medicare and medicaid, although the timing of the changes do not match up. ${ }^{8}$ Bernheim et al. (2001) model differences in retirement wealth among U.S. households find little evidence for the life-cycle saving theory.

In short, the literature agrees that the private saving rate in the U.S. has been on a long decline but there is no consensus on the cause. There is no consistent evidence that the decline can be traced to changes in tax and transfer polices, to federal deficits, or to demographic trends. Because saving is evidently important for understanding the current account, we want to be able to model the evolving saving rate in the context of an open economy macro model. We do this in the next section by endogenizing the subjective discount factors.

\section{A two-country endogenous discount endowment model}

This section presents the two-country one-good endowment model that underlies our quantitative analysis. Each country, $j=1,2$, is inhabited by identical infinitely lived households that consists of $N_{j, t}$ members. The number of household members in each country grows at the constant rate $n=\ln N_{j, t+1}-\ln N_{j, t}$. Each household member owns a nonstorable endowment stream yielding $y_{j, t}$ units each period.

Budget constraints. Households in each country can exchange goods and a non-state contingent

\footnotetext{
${ }^{8}$ In Bosworth's discussion of the paper he notes that introduction of medicare and medicaid and the expansion of social security benefits were largely completed by the early 1970s but the national saving rate did not decline until the $1980 \mathrm{~s}$.
} 
bond that is in zero net supply. The real price of the bond is $v_{t}$ and a bond issued at $t-1$ pays one unit of the consumption good at $t$. At $t$, income for a member of a household in country $j$ is the payoff from bonds purchased last period $b_{j, t-1}$ and the endowment $y_{j, t}$ which is spent on consumption and new bond holdings $v_{t} b_{j, t} \cdot{ }^{9}$ If $c_{j, t}$ is household consumption in country $j$, the aggregate budget constraints for country $j=1,2$ is

$$
N_{j, t} c_{j, t}+v_{t} N_{j, t} b_{j, t} \leq N_{j, t} y_{j, t}+N_{j, t-1} b_{j, t-1}
$$

Preferences. Engel and Rogers (2006) show that the FDF representative agent macro model does not give a satisfactory explanation for the U.S. current account. One salient feature of the data that it will have trouble explaining is the trending saving rate. To account for the evolution of saving behavior, which appears to be a key factor behind the current account deterioration, we assume that consumers discount factors $\theta_{j, t}$, depend on societal or per capita consumption which varies over time. Thus, a country $j$ household seeks to maximize

$$
E_{0} \sum_{t=0}^{\infty} \theta_{j, t-1} u\left(c_{j, t}\right) N_{j, t},
$$

subject to the budget constraint (1) where period utility for a member of the household is the constant relative risk aversion function

$$
u\left(c_{j, t}\right)=\frac{c_{j, t}^{1-\gamma}}{1-\gamma},
$$

where $\gamma \geq 0$ is the coefficient of relative risk aversion.

Let $\bar{c}_{j, t}$ be societal consumption at $t$ and $\bar{c}_{j, t}^{*}$ be the steady-state value of societal consumption along a balanced growth path. In the symmetrical equilibrium, consumption is identical across individuals within the country so there will be no difference between societal and individual consumption. At this point, however, it is useful as an expositional device to maintain

\footnotetext{
${ }^{9}$ When we evaluate the FDF model, we will impose a small cost upon the household to participate in the bond market $\xi\left(v_{t} b_{1, t}\right)^{2} /\left(2 y_{1, t}\right)$, which ensures that a stationary steady state exists. If the cost parameter $\xi=0$, the steady state level of bond holdings will be dependent on initial conditions. Similarly, a member of a foreign household will bear a cost of $\xi\left(v_{t} b_{2, t}\right)^{2} /\left(2 y_{2, t}\right)$ to participate in the bond market. In the simulations and empirical work, we set $\xi$ to a very small number so as to be largely inconsequential in characterizing the short-run dynamics. In this case, the budget constraints become for $j=1,2$,

$$
N_{j, t} c_{j, t}+v_{t} N_{j, t} b_{j, t}+\frac{\xi}{2} \frac{N_{j, t}\left(v_{t} b_{j, t}\right)^{2}}{y_{j, t}} \leq N_{j, t} y_{j, t}+N_{j, t-1} b_{j, t-1}
$$
}


the distinction because the household views societal consumption as external to its maximization problem and does not take into account how its consumption choice affects the discount factor.

Temporary divergences between $\bar{c}_{j, t}$ and $\bar{c}_{j, t}^{*}$ cause the subjective discount factor $\theta_{j, t}$ to vary over time according to the three $(\beta, \eta, \psi)$ parameter model

$$
\begin{aligned}
& \theta_{j, t}=\theta_{j, t-1} \beta_{j, t}=\theta_{j,-1} \prod_{i=0}^{t} \beta_{1, t-i}, \\
& \beta_{j, t}=\beta_{j, t-1}^{\eta}\left[\left(\frac{\bar{c}_{j, t}}{\bar{c}_{j, t}^{*}}\right)^{-\psi} \beta\right]^{(1-\eta)},
\end{aligned}
$$

where $\eta \in[0,1], \beta \in[0,1], \psi \in[0, \bar{\psi}), \bar{\psi}<\infty$, with initial conditions $b_{j,-1}, \theta_{j,-1}$ and $\beta_{j,-1}$ given. ${ }^{10}$ The subjective discount factor is such that people become increasingly impatient when societal consumption exceeds its steady-state value. Current impatience is also partly inherited from the past where the parameter $\eta$ directly regulates the persistence in the period discount factor $\beta_{j, t}$. The FDF specification, which is a modest generalization of the Engel and Rogers (2006) 'shares' model, is nested within the EDF model and can be obtained by setting $\eta=1$ and $\psi=0$.

Other researchers, such as Mendoza (1991), Schmidt-Grohe (1998), Schmidt-Grohe and Uribe (2003), and Kim and Kose (2003) have employed EDF specifications. These authors construct models of small open economies with incomplete markets and an exogenous real interest rate and introduce EDFs as a device to induce a stationary steady state. The main difference between our EDF and theirs is that we allow persistence in $\beta_{j, t}$. The common feature of the alternative specifications is that impatience is increasing with consumption. ${ }^{11}$ This may seem counterintuitive but the effect is temporary. The heightened impatience lasts only as long as consumption lies above the steady-state level. Bian and Meng (2004) and Meng (2006) study how indeteterminancies can arise in models with socially determined discount factors. Such indeterminacies do not occur in our specification.

Aggregate equilibrium conditions. We rewrite the household's problem in terms of aggregates. Let upper case letters denote the aggregate of the lower case variables, $X_{j, t}=N_{j, t} x_{j, t}$, where

\footnotetext{
${ }^{10}$ Let $\tilde{c}_{t}=\ln c_{1, t}-\ln c_{2, t}$. Ignoring constant terms, log-linearizing the risk-sharing condition gives $\widetilde{c}_{t+1}=$ $\left[\eta+1-\frac{\psi(1-\eta)}{\gamma}\right] \widetilde{c}_{t}-\eta \widetilde{c}_{t-1}+v_{t}-\eta v_{t-1}$ where $v$ is an expectation error. For $\eta \in[0,1]$, relative consumption will be a stationary process if $\psi$ is chosen such that the solutions to $z^{2}-\left[\eta+1-\frac{\psi(1-\eta)}{\gamma}\right] z+\eta=0$ lie outside the unit circle. $\bar{\psi}$ is the upper bound of $\psi$ such that this is condition holds.

${ }^{11}$ Abstracting away from a labor decision, the period discount factor employed by those authors $\beta_{t}=$ $\left(1+c_{t-1}\right)^{-\psi}$. They choose $\psi$ to match the average trade-balance to GDP ratio.
} 
$x_{j, t}$ a variable for a household member. Then household lifetime discounted expected utility can be rewritten as

$$
E_{0} \sum_{t=0}^{\infty} \theta_{j, t-1} \frac{C_{j, t}^{1-\gamma} N_{j, t}^{\gamma}}{1-\gamma}
$$

where the subjective discount factor $\theta_{j, t}$, evolves as in (2), with

$$
\beta_{j, t}=\beta_{j, t-1}^{\eta}\left[\left(\frac{\bar{C}_{j, t}}{\bar{C}_{j, t}^{*}}\right)^{-\psi} \beta\right]^{(1-\eta)} .
$$

In equilibrium, a household member's consumption coincides with societal consumption $c_{j, t}=$ $\bar{c}_{j, t}$. For $j=1,2$, the budget constraints can be rewritten in terms of aggregates as

$$
C_{j, t}+v_{t} B_{j, t} \leq Y_{j, t}+B_{j, t-1}
$$

From the household's problem, we obtain for $j=1,2$, the bond Euler equations

$$
v_{t}=\beta_{j, t} E_{t}\left(\frac{C_{j, t+1}}{C_{j, t}}\right)^{-\gamma}\left(\frac{N_{j, t+1}}{N_{j, t}}\right)^{\gamma} .
$$

The model is closed by the zero-net supply constraint on bonds

$$
B_{1, t}+B_{2, t}=0,
$$

the resource constraint

$$
Y_{1, t}+Y_{2, t}=C_{1, t}+C_{2, t},
$$

and a first-order vector autoregression (VAR(1)) that governs the endowments

$$
\left(\begin{array}{l}
\ln Y_{1, t}-\delta_{1}-g t \\
\ln Y_{2, t}-\delta_{2}-g t
\end{array}\right)=\left(\begin{array}{ll}
a_{11} & a_{12} \\
a_{21} & a_{22}
\end{array}\right)\left(\begin{array}{c}
\ln Y_{1, t-1}-\delta_{1}-g(t-1) \\
\ln Y_{2, t-1}-\delta_{2}-g(t-1)
\end{array}\right)+\left(\begin{array}{c}
\varepsilon_{1, t} \\
\varepsilon_{2, t}
\end{array}\right),
$$

where $\delta_{1}, \delta_{2}$ are constant terms, $\left(\varepsilon_{1, t}, \varepsilon_{2, t}\right)^{\prime} \stackrel{i i d}{\sim} N\left(0, \boldsymbol{\Sigma}_{\varepsilon}\right)$, and $g$ is the common growth rate of the endowments. Note that $\delta_{1}-\delta_{2}$ determines the relative size of the country 1 endowment in the steady state. We impose a common growth rate to be consistent with a balanced-growth requirement. The quantitative analysis that follows below works with aggregate observations detrended at this rate $g$. The appendix describes the model in terms of detrended aggregates.

Two other variables of interest are the trade balance to GDP ratio

$$
t b_{t}=\frac{Y_{1, t}-C_{1, t}}{Y_{1, t}}
$$

and the current account balance to GDP ratio

$$
c a_{t}=t b_{t}+\frac{\left(1-v_{t-1}\right) B_{1, t-1}}{Y_{1, t}} .
$$


We note that our model is related to Yi's (1993) two-country endowment model where households value government purchases, $G$. In his model, the period utility function is constant relative risk aversion in a Cobb-Douglas index of consumption goods and government purchases. The counterpart of the bond Euler equation (4) in his paper is

$$
v_{t}=\left(\frac{G_{j, t+1}}{G_{j, t}}\right)^{(1-\alpha)(1-\gamma)}\left(\frac{C_{j, t+1}}{C_{j, t}}\right)^{\alpha(1-\gamma)-1},
$$

where $\alpha$ is the share of government spending in the consumption index and $\gamma$ is the coefficient of relative risk aversion. For values of $\gamma>1$ (so that $(1-\alpha)(1-\gamma)<0$ ) the growth of government purchases in his model works in the same way as increasing impatience but he is unable to explain the trade balance data by setting $\gamma=2$,. To get close to the data, he requires $\gamma=0.2$ and that agents anticipate in 1981 that $G$ will decline by 10 percent by 1988 . The sudden recognition of persistently falling government consumption causes $\left(\frac{G_{j, t+1}}{G_{j, t}}\right)^{(1-\alpha)(1-\gamma)}$ to be decreasing over time which simulates increasing impatience.

\subsection{Assigning parameter values}

We take the U.S. to be country 1 and the ROW to be country 2. For the period utility function, we set the coefficient of relative risk aversion $\gamma=2$ in accordance with commonly used values in the literature. Parameters for the process (5) governing the endowment $(Y-I-G)$ are obtained by estimating a bivariate VAR with a common trend coefficient $g$ for both countries. The estimates, shown in Table 2, exhibit relatively low persistence for the ROW and negative spill-over effects $\left(a_{12}, a_{21}<0\right)$.

Table 2: VAR coefficients

\begin{tabular}{ccc}
\hline \hline Parameter & Estimate & (s.e.) \\
\hline$g$ & 0.029 & $(0.0004)$ \\
$\delta_{1}$ & 28.710 & $(0.008)$ \\
$\delta_{2}$ & 29.063 & $(0.008)$ \\
$a_{11}$ & 0.754 & $(0.105)$ \\
$a_{12}$ & -0.117 & $(0.094)$ \\
$a_{21}$ & -0.319 & $(0.243)$ \\
$a_{22}$ & 0.198 & $(0.218)$ \\
$\sigma_{11}$ & $0.011^{2}$ & \\
$\sigma_{12}$ & $0.0075^{2}$ & \\
$\sigma_{22}$ & $0.027^{2}$ & \\
\hline \hline
\end{tabular}


We set the steady-state discount factor $\beta=0.96$. We are unable to draw upon the literature to set $\eta$ and $\psi$ since existing work with EDF models do not allow for persistence. Thus, to obtain these values we estimate $\eta$ and $\psi$ by generalized method of moments (GMM). The GMM problem seeks to match moments for relative consumption implied by the model to sample moments computed from in the data. We use the first moment of relative consumption, the variance and first-order autocorrelation of relative consumption levels and the variance and first-order autocorrelation of the deviation of relative consumption from a trend. ${ }^{12}$

Table 3: GMM estimates

\begin{tabular}{ccl}
\hline \hline Parameter & Estimate & (s.e.) \\
\hline$\eta$ & 0.952 & $(0.001)$ \\
$\psi$ & 0.543 & $(0.007)$ \\
J-statistic & 6.157 & \\
p-value & 0.104 & \\
\hline \hline
\end{tabular}

The parameter estimates are shown in Table 3. $\eta$ and $\psi$ are precisely estimated as seen by the small standard errors relative to the estimated values. The relatively large value of the estimated $\eta$ says that the discount factors exhibit a high degree of persistence. The data supports the EDF specification in that the test of three overidentifying restrictions has a pvalue of 0.104 which does not reject the model at standard significance levels.

\subsection{Properties of the model}

This section examines the dynamic properties of the model through impulse response analysis. To fix ideas, we begin with the properties of the standard FDF model. Figures 5 and 6 show the impulse-response from a one standard deviation shock to U.S. endowment. Home and foreign consumption are seen to be highly positively correlated. A positive U.S. endowment shock initially raises home consumption but by less than the increase in the endowment giving rise to a current account surplus. The desire to smooth consumption intertemporally causes U.S. residents to want to share some of the extra endowment with the ROW. Due to the

\footnotetext{
${ }^{12}$ Schmidt-Grohe and Uribe (2003) and Kim and Kose (2003) set their counterpart to $\psi$ to match the average trade-balance to GDP ratio.
} 
negative spillover effect, ROW's endowment falls in the following period. As in Baxter and Crucini (1995), the internationally traded bond provides a substantial amount of risk sharing across countries. The U.S. shares some of its endowment gain with ROW and consumption increases at home and abroad. The ROW pays for the additional consumption by issuing debt to the U.S. thereby improving the U.S. current account. Over the longer run, foreign debt service allows the U.S. to run a trade deficit and to enjoy higher relative consumption. The apparently procyclical current account and the high comovements of consumption are counterfactual implications of the FDF model. ${ }^{13}$

The impulse responses under EDF are strikingly different and appear to be more consistent with the stylized facts. In Figure 7, an innovation to the U.S. endowment leads to a more than a proportionate increase in consumption which lowers the saving ratio. In the initial period, high relative U.S. consumption lowers the equilibrium discount factor to make the U.S. relatively impatient. The U.S. trade and current accounts worsen immediately since the relatively high U.S. endowment is not sufficient to cover the even higher consumption. Domestic dissaving is observed for the first several periods as U.S. consumption lies above the home endowment. The short-run worsening of the current account and its apparent countercyclical nature under the EDF specification contrasts sharply with the response in the FDF model. Instead of triggering increased saving due to the consumption smoothing motive, the endowment shock creates a surge in consumption financed by borrowing from foreigners.

A qualitative feature of the EDF model is that agents engage in buffer stock saving. Buffer stock saving has been studied in a series of papers by Carroll (1997, 2001, 2004). He shows for finitely lived consumers with no bequest motive, impatience and the precautionary saving motive work in opposite directions when consumers are moderately impatient. Because very poor agents are less able to buffer consumption against adverse shocks, the precautionary saving motive becomes stronger as wealth declines. The point at which impatience and the precautionary motive offset each other defines a target level of wealth. When wealth rises above this target, impatience dominates and wealth begins to fall and when wealth falls below the target, the precautionary motive dominates and wealth begins to rise. In the EDF model, when domestic societal consumption rises above steady-state consumption, home agents become impatient and net foreign assets decline. ${ }^{14}$

Figure 8 shows the reallocations of relative wealth that are transmitted through the current account. The positive innovation to the U.S. endowment temporarily raises the present value

\footnotetext{
${ }^{13}$ Backus et al. (1992) document the countercyclicality of the trade balance and the low (relative to output) correlation of national consumption.

${ }^{14}$ In Carroll (1997), prudence is characterized by the existence of precautionary saving and impatience by consumption in excess of income in a world of certainty. The utility function that we employ exhibits both of these properties.
} 
of U.S. endowment income. Impatience and consumption rises, the net foreign asset position declines and the U.S. current account deteriorates immediately. The negative spill-over effects causes the present value of ROW endowment to fall. ROW consumption falls which makes them more patient. The ROW desires to run a current account surplus beginning immediately. This contrasts with the FDF specification where the positive innovation to U.S. endowment results in a permanent increase in U.S. wealth relative to ROW.

Looking beyond the impact effects, the transition back to the steady state is oscillatory rather than monotonic as in the FDF model. The positive endowment shock that initially raised U.S. consumption makes domestic agents relatively impatient and generates domestic dissaving. Over time, as the ROW becomes relatively wealthier and the U.S. becomes relatively poorer, the ROW becomes impatient relative to the U.S. During this time, ROW consumption rises, U.S. consumption falls and the current account improves. The model exhibits a rich set of transition dynamics during which home and foreign consumption are negatively correlated.

Sensitivity to variations in $\eta$ and $\psi$. Here, we examine the sensitivity of the impulse responses to variations in the discount factor parameters $\eta$ and $\psi$. Recall that the EDF approaches the $\mathrm{FDF} \beta$ as $\psi(1-\eta) \rightarrow 0$.

We begin by examining variations in $\eta$. Figure 9 shows the response of the relative U.S. to ROW discount factor for $\eta=(0.97,0.9,0.8,0.6)$ with all other parameters set at their baseline values. The persistence in the discount factor is seen to be increasing in $\eta$ and the volatility decreasing in $\eta$. The persistence and volatility of the discount factor plays a pivotal role in determining the persistence and volatility of consumption and the current account. Figure 10 shows the response in U.S. consumption and Figure 11, the response in ROW consumption for alternative values of $\eta$. Higher values increase the persistence of the consumption responses. The excess U.S. consumption and associated current account deterioration that follows the endowment shock is robust to the range of $\eta$ values considered.

Next, we examine the effect of variations in the elasticity of the EDF to consumption $\psi$. Figure 12 shows the response of the relative discount factors for $\psi=(0.8,0.6,0.3,0.2)$ with all other parameters set at their baseline values. While the most noticeable effect of variations in $\psi$ on the discount factor is on volatility, which is increasing in $\psi$, persistence is seen to be decreasing in $\psi$. Figures 13 and 14 show the U.S. and ROW consumption responses that follow an innovation to the U.S. endowment. For $\psi=0.8$ and 0.6 , ROW consumption declines upon impact and U.S. consumption lies above the endowment. The immediate worsening of the current account, shown in Figure 15, is robust to these values of $\psi$. Smaller values of $\psi$ brings the model closer to the FDF dynamics, however, as it attenuates U.S. impatience following the shock. For $\psi=0.3$ and 0.2 , there is an initial span of time where the U.S. current account is in surplus before turning into a deficit. 
To summarize, the parameters $\eta$ and $\psi$ control both the volatility and the persistence in the discount factors, consumption, and current account responses. The impulse responses look more like those from the FDF specification for small values of $\psi$, which is expected since it is nested within the EDF model and obtains when $\psi(1-\eta)=0$.

\section{Understanding the U.S. current account}

We now turn to our main objective and ask to what extent the model can explain the modern U.S. current account experience. We bypass the exercise of looking at the model's ability to match various moments of the data and seek to understand the entire time-path of the data. We present agents in the model with the endowment data as a realization of the state vector and compare the external balances implied by their consumption choices to the current account data.

Fixed discount factor model. To form a basis of comparison, we again start with the predictions from the model under FDF. Figure 16 displays the exact choices by agents in the model along with the data. Here, we see that from 1983 onwards, the standard model predicts a sustained improvement in the current account which goes in the wrong direction. The correlation between the predicted and actual current account is -0.67 . The implied current account improves because the increase in relative U.S. endowment induces U.S. residents to carry the endowment gains into the future by increased saving. Owing to the steady rise in the U.S. share of world endowment, the model predicts a counterfactual ongoing improvement in the current account. The predicted current account path that we obtain is qualitatively similar to the predictions of Engel and Rogers' (2006) 'shares' model.

Engel and Rogers argue that one way for their model to generate a worsening of the current account is if agents continually underpredict the U.S. share of GDP. They report evidence to support such underprediction using survey data from Consensus Forecasts. However, they are not successful in generating revisions of rational expectations of the size necessary to account for the data using reasonable parametric specifications the income shares process.

Endogenous discount factor model. The data and the predicted current account under EDF

are shown in Figure 17. As can be seen, the model explains quite well the negative trend of the current account. The correlation between the predicted and actual current account is 0.566. The model also generates fluctuations around the trend that are of the correct magnitude, but does less well in timing the cyclical fluctuations. The model misses the data from 1981 to 1991. From 1981 to 1985, the model predicts an improvement while the actual current account 
deteriorates. From 1987 to 1991, the model predicts a worsening while the current account improved.

The worsening current account predicted by the model is driven by the persistent and increasing impatience of the U.S. vis-a-vis the ROW. Figure 18 shows the percentage deviation from the steady state of the relative U.S. discount factor. Over the sample period, the relative U.S. annual rate of time preference decreased by 0.148 basis points per annum on average.

Projections for unwinding the current account deficit. Here, we use the model to predict the time-paths for achieving current account balance from a position of a $5.7 \%$ deficit relative to GDP. We report the model's estimate on the length of the transition and upon the dynamics of the current and trade account adjustment. The estimates are formed from choices made by model agents where given the year 2004 state of the world, all future U.S. and ROW endowments shocks are set to zero. ${ }^{15}$

The model's projections are shown in Figure 19. The trade balance is projected to remain in deficit until 2020 and the current account deficit is projected to improve through 2030 when it goes into surplus. Given the minimalist setup of the model and the absence of any rigidities, the model projects only soft-landings although the transition phase can last a long time. The projected path of the U.S. net foreign asset position is shown in Figure 20 which declines to a whopping 81 percent of GDP three years after the trade deficit is erased.

The model seems to predict that the ongoing worsening of the U.S. current account deficit may soon be resolved in the absence of future endowment shocks. Naturally, the transition to a balanced current account will be hastened if the rest-of-world experiences relatively more rapid endowment growth.

\section{Conclusions}

To rephrase a statement from Nason and Rogers (2006), current account trends resist easy explanations. In this paper, we attempt to provide a quantitative explanation of the sustained negative trend in the U.S. current account using the simplest possible framework; a two-country endowment model that is standard in all respects except that subjective discount factors are endogenous. In allowing societal consumption levels to influence the subjective discount factor, we are able to account for the sustained worsening of the current account and the evolving and saving rates at home and abroad. The resulting model improves over the standard model with fixed subjective discounting.

\footnotetext{
${ }^{15}$ Since the rest-of-world endowments from 2004 are not available, we use forecasted values from the estimated VAR process.
} 
While we have limited our investigation to an endowment model we view the effort as an intermediate step towards a complete understanding of the U.S. current account. The model struggles to explain the cyclical fluctuations during the period from 1981 to 1991. While investment flows do not appear to be important for understanding the long-term current account trend, they may be important for understanding cyclical aspects. Alternatively, the unusual cyclical behavior of the data during this period coincided with the Volker stabilization of U.S. inflation suggesting that a full understanding may require a model with money. Extending the model to a production economy and the introduction of money are two directions for future work. 


\section{References}

[1] Attanasio, Orazio P.(1998). "Cohort Analysis of Saving Behavior by U.S. Households," The Journal of Human Resources, 33(3), Summer, 575-609.

[2] Backus, David K., Patrick J. Kehoe and Finn E. Kydland, (1992). "International Real Business Cycles," Journal of Political Economy, 4, 745-777

[3] Baxter, Marianne and Mario J. Crucini, (1995). "Business Cycles and the Asset Structure of Foreign Trade," International Economic Review, 36, 821-854

[4] Bergin, Paul R. (2006). "How Well Can the New Open Economy Macroeconomics Explain the Exchange Rate and the Current Account?" Journal of International Money and Finance, 25(5), August, 675-701.

[5] Bergin, Paul R. and Steven M. Sheffrin, (2000). "Interest Rates, Exchange Rates, Present Value Models of the Current Account," Economic Journal, 110(463), April, 535-558.

[6] Bernanke, Ben S. (2005). "Remarks by Governor Ben S. Bernanke at the Sandridge Lecture, Virginia Association of Economics, Richmond, Virginia." http://www.federalreserve.gov/boarddocs/speeches/2005/200503102/default.htm.

[7] Bernheim, B. Douglas, Jonathan Skinner and Steven Weinberg, (2001). "What Accounts for the Variation in Retirement Wealth among U.S. households?" American Economic Review, 91(4), September, 832-857.

[8] Bian, Yong and Qinglai Meng, (2004). "Preferences, Endogenous Discount Rate, and Indeterminacy in a Small Open Economy Model,' Economics Letters, 84(3), September, $315-322$

[9] Blanchard, Olivier, Francesco Giavazzi and Filipa Sa, (2005). "The U.S. Current Account and the Dollar," NBER working paper No. 11137.

[10] Bosworth, Barry, Gary Burtless and John Sabelhaus, (1991). "The Decline in Saving: Evidence from Household Surveys," Brookings Papers on Economic Activity, 1991(1), $183-256$.

[11] Bussière, Matthieu, Marcel Fratzscher and Gernot J. Müller, (2005). "Productivity Shocks, Budget Deficits and the Current Account," European Central Bank Working Paper No. 509.

[12] Carroll, Christopher D., (1997). "Buffer-Stock Saving and the Life Cycle/Permanent Income Hypothesis," Quarterly Journal of Economics, 92, 1-55.

[13] Carroll, Chrisopher D., (2001). "A Theory of the Consumption Function With and Without Liquidity Constraints," Journal of Economic Perspectives, 15, 23-45. 
[14] Carroll, Christopher D., (2004). "Theoretical Foundations of Buffer-Stock Saving," mimeo, Johns Hopkins University.

[15] Chinn, Menzie D. and Eswar S. Prasad (2003). "Medium-term Determinants of Current Accounts in Industrial and Developing Countries: An Empirical Exploration," Journal of International Economics, 59(1), January, 47-76.

[16] Chinn, Menzie D. and Hiro Ito (2005). "Current Account Balances, Financial Development and Institutions: Assaying the World 'Savings Glut'," NBER working paper No. 11761.

[17] Corsetti, Giancarlo and Gernot J. Müller, (2006). 'Twin Deficits: Squaring Theory, Evidence and Common Sense,' Economic Policy, 21(48), October, 597-638.

[18] Domeij, David and Martin Floden, (2006). "Population Aging and International Capital Flows," International Economic Review, 47, 1013-1032.

[19] Dooley, Michael P., David Folkerts-Landau and Peter M. Garber, (2004). "The U.S. Current Account Deficit and Economic Development: Collateral for a Total Return Swap," NBER working paper No. 10727.

[20] Dooley, Michael P., David Folkerts-Landau and Peter M. Garber, (2005). "Savings Gluts and Interest: The Missing Link to Europe," NBER working paper No. 11520.

[21] Edwards, Sebastian, (2005). "Is the U.S. Current Account Deficit Sustainable? And If Not, How Costly Is Adjustment Likely To Be?" Brookings Papers on Economic Activity, 2005(1), 211-288.

[22] Engel, Charles, and John H. Rogers, (2006). "The U.S. Current Account Deficit and the Expected Share of World Output," Journal of Monetary Economics, 53(5), July, 1063-1093.

[23] Faruqee, Hamid, Douglas Laxton, Dirk Muir and Paolo Pesenti, (2005). "Smooth Landing or Crash? Model-Based Scenarios of Global Current Account Rebalancing," NBER Working Paper No. 11583.

[24] Ghironi, Fabio, Talan B. İşcan, and Alessandro Rebucci, (2005). "Net Foreign Asset Positions and Consumption Dynamics in the International Economy," International Monetary Fund Working Paper WP/05/82.

[25] Gokhale, Jagadeesh, laurence J. Kotlikoff and John Sabelhaus, (1996). "Understanding the Post-War Decline in U.S. Saving: A Cohort Analysis," Brookings Papers on Economic Activity, 1996(1), 315-390.

[26] Gourinchas, Pierre Olivier, and Helene Rey, (2005). "From World Banker to World Venture Capitalist: The U.S. External Adjustment and the Exorbitant Privilege," NBER working paper No. 11563. 
[27] Granger, C.W.J., and P. Newbold, (1974). "Spurious Regressions in Economics," Journal of Econometrics. July, 2(2): 111-120.

[28] Gruber, Joseph W. and Steven B. Kamin, (2005). "Explaining the Global Pattern of Current Account Imbalances," Board of Governors of the Federal Reserve System International Finance Discussion Paper No. 846.

[29] Kim, Sunghyun and M. Ayhan Kose, (2003). "Dynamics of Open-Economy Business-Cycle Models: Role of the Discount Factor," Macroeconomic Dynamics, 7(2), April, 263-290.

[30] Mann, Catherine L., (1999). Is the U.S. Trade Deficit Sustainable? Washington D.C.: Institute for International Economics.

[31] Mendoza, Enrique, (1991). "Real Business Cycles in a Small-Open Economy," American Economic Review 81(4), September, 797-818.

[32] Meng, Qinglai, (2006). "Impatience and Equilibrium Indeterminacy," Journal of Economic Dynamics \& Control, 30(12), December, 2671-2692

[33] Nason, James, and John H. Rogers, (2006). "The Present-Value Model of the Current Account Has Been Rejected: Round Up the Usual Suspects," Journal of International Economics, 86(1), January, 159-187.

[34] Obstfeld, Maurice, (1982). "Aggregate spending and the terms of trade: Is there a LaursenMetzler effect?" Quarterly Journal of Economics, 97(2), May, 251-270.

[35] Obstfeld, Maurice, and Kenneth Rogoff (2004), "The Unsustainable US Current Account Position Revisited," NBER working paper No. 10869.

[36] Park, Joon Y. (1990). "Testing for Unit Roots and Cointegration by Variable Addition," in Fomby, Thomas B.; Rhodes, George F., Jr., eds., Co-integration, spurious regressions, and unit roots. Advances in Econometrics series, vol. 8, Greenwich, Conn. and London: JAI Press, 107-133.

[37] Schmitt-Grohé, Stephanie, (1998). "The International Transmission of Economic Fluctuations: Effects of U.S. Business Cycles on the Canadian Economy," Journal of International Economics, 44(2), April, 257-287.

[38] Schmitt-Grohé, Stephanie and Martin Uribe (2003). "Closing Small Open Economy Models," Journal of International Economics, 61, 163-185.

[39] Summers, Lawrence, Chris Carroll and Alan S. Blinder, (1987). "Why is U.S. National Saving So Low?" Brookings Papers on Economic Activity, 1987(2), 607-642.

[40] Yi, Kei-Mu, (1993). "Can Government Purchases Explain the Recent U.S. Net Export Deficits?" Journal of International Economics 35, 201-225. 


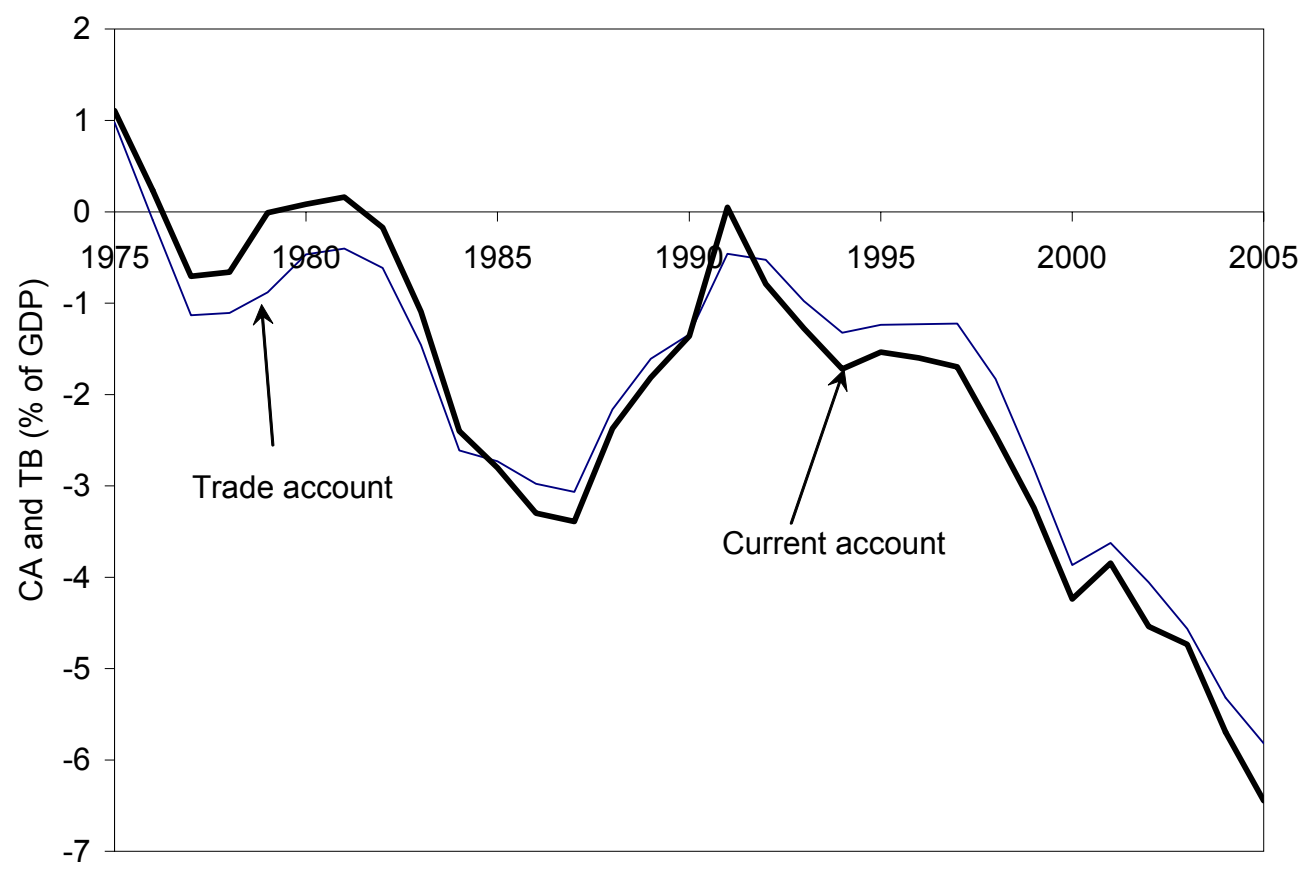

Figure 1. The data

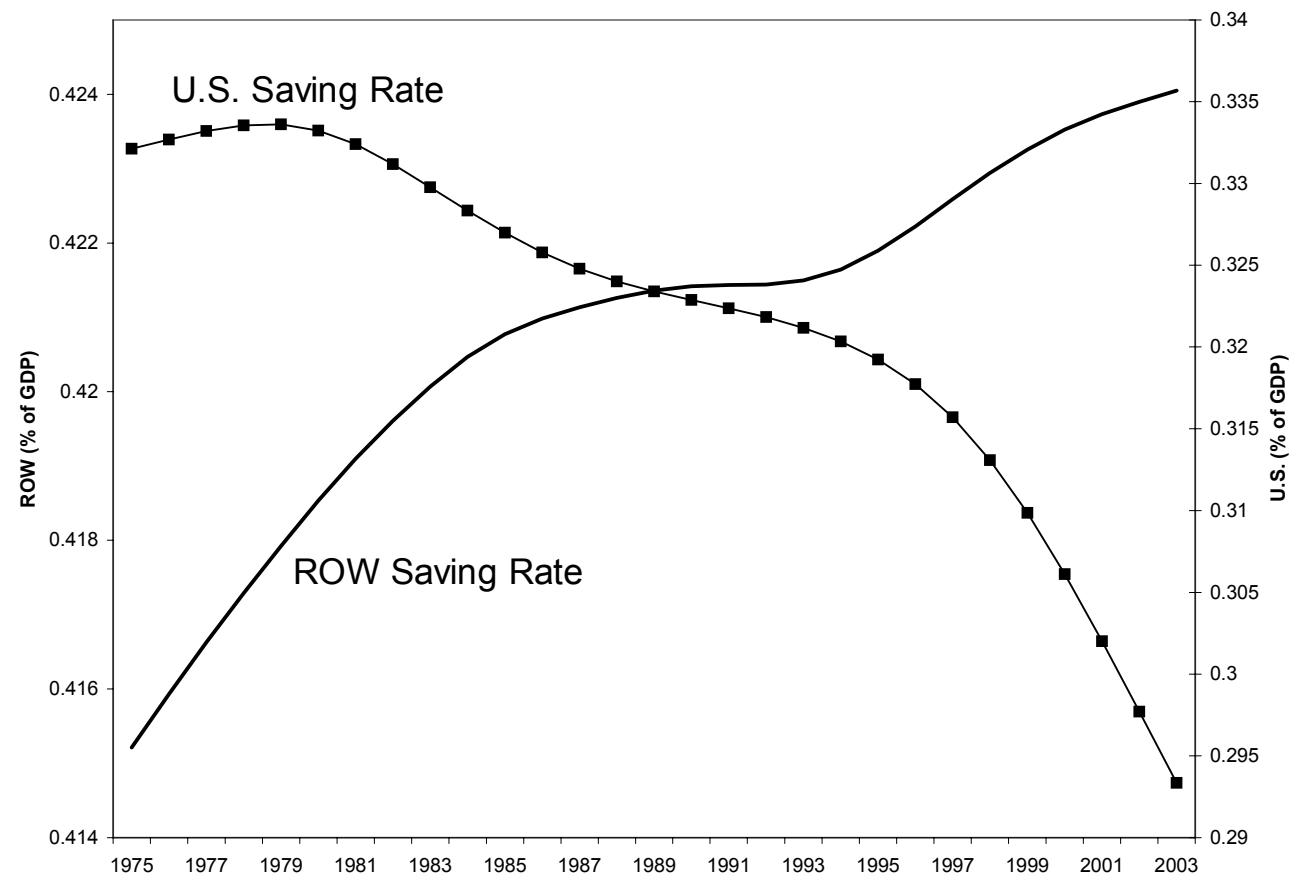

Figure 2. Saving rate trends 


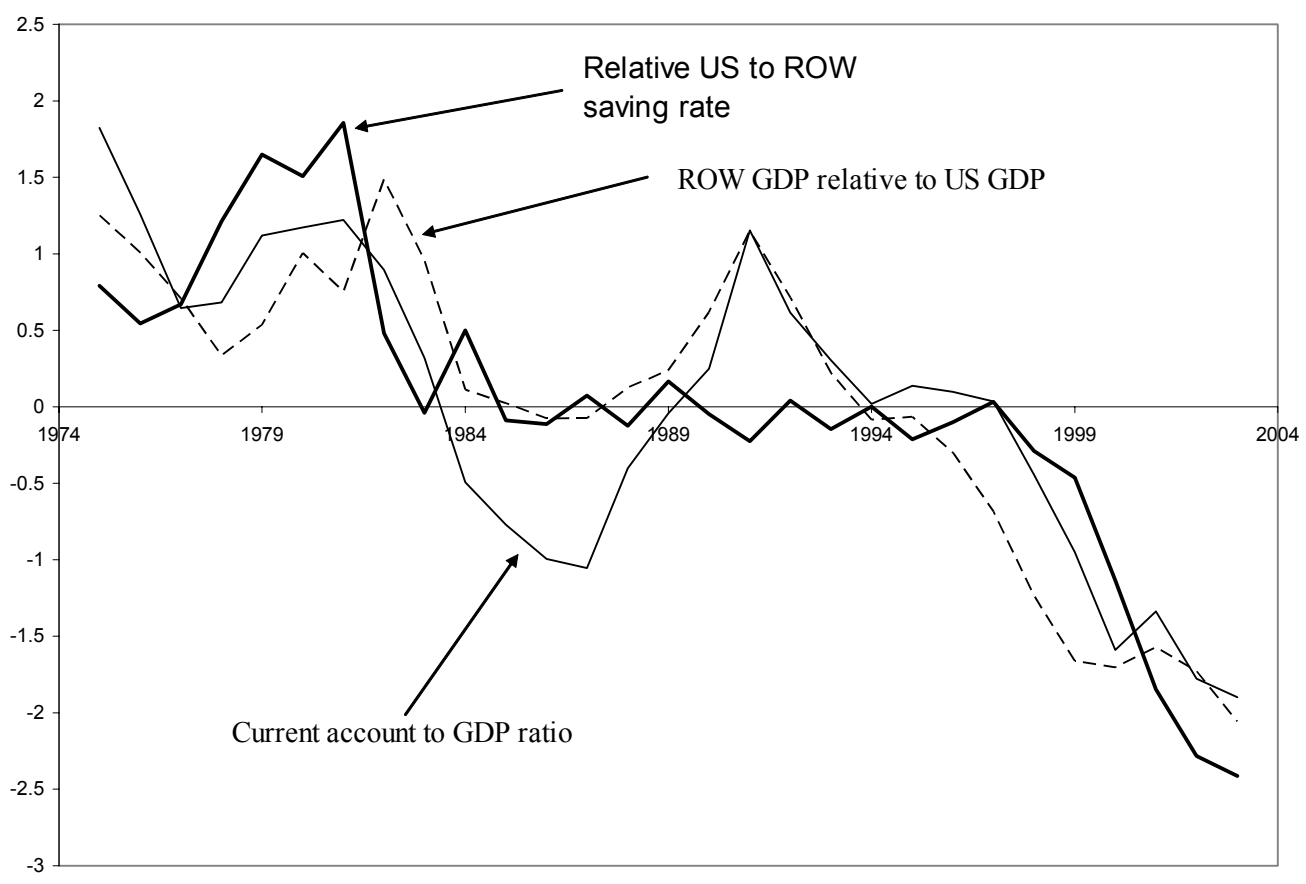

Figure 3. Standardized current account to GDP ratio, relative household saving rates and income shares.

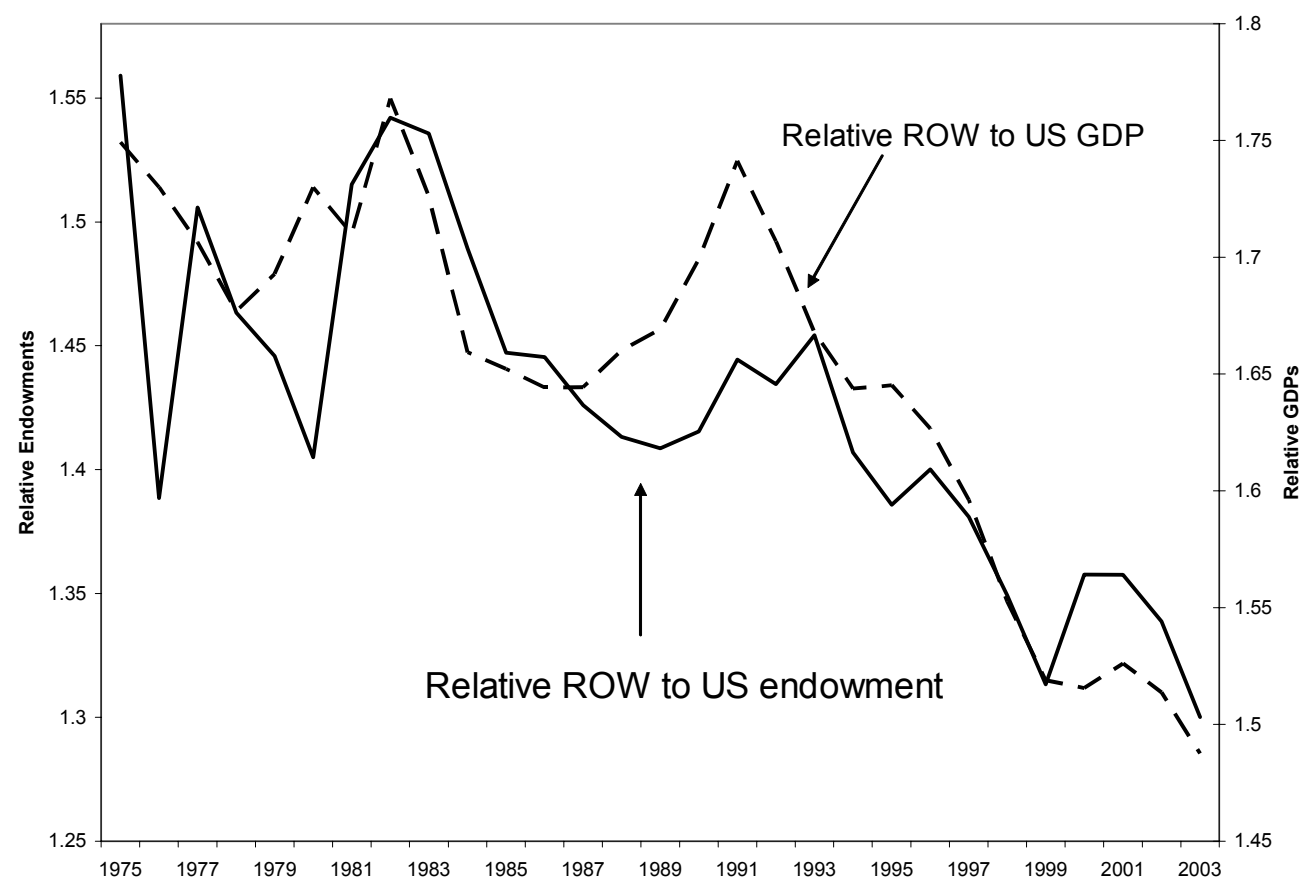

Figure 4. Relative GDP and relative endowments 


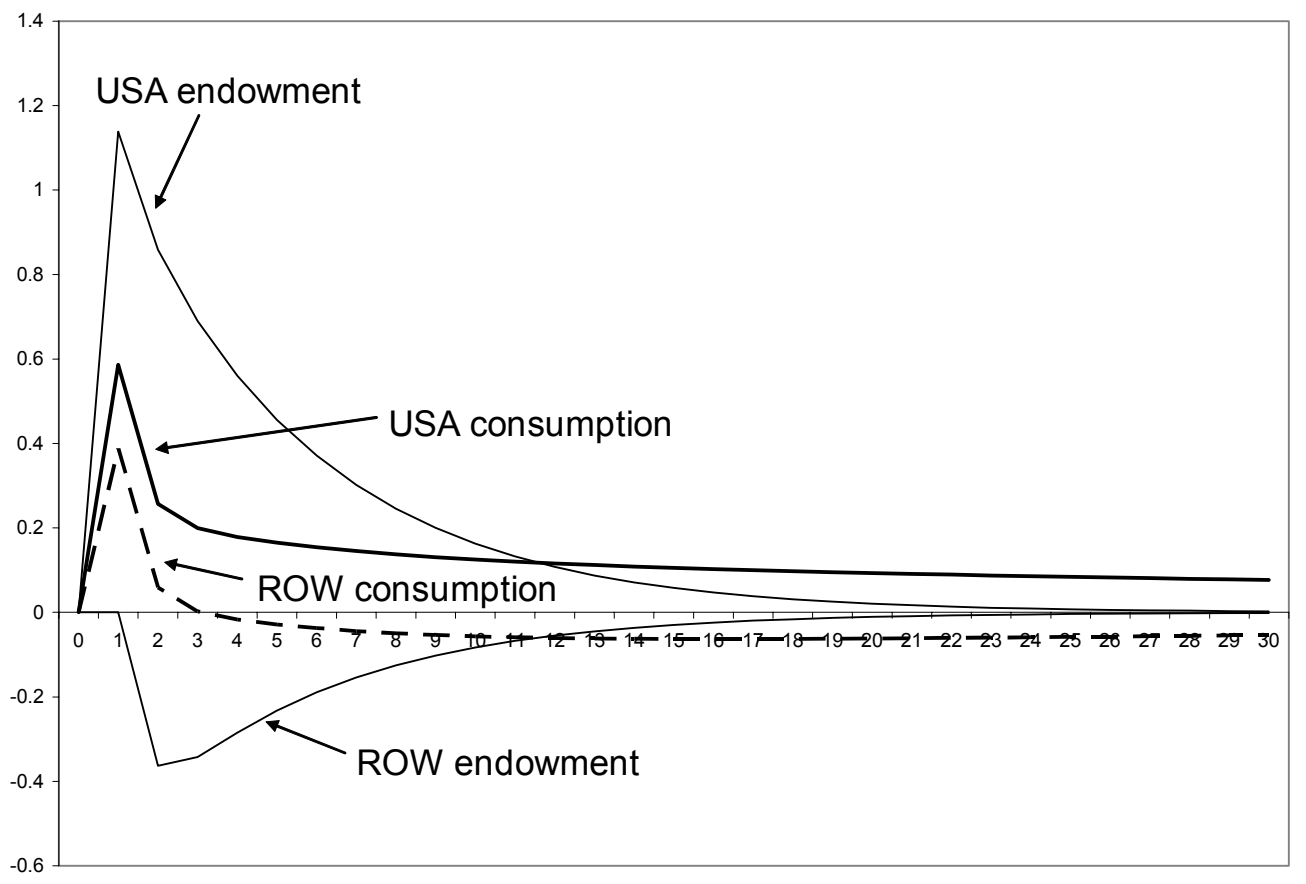

Figure 5. Consumption in standard (FDF) model

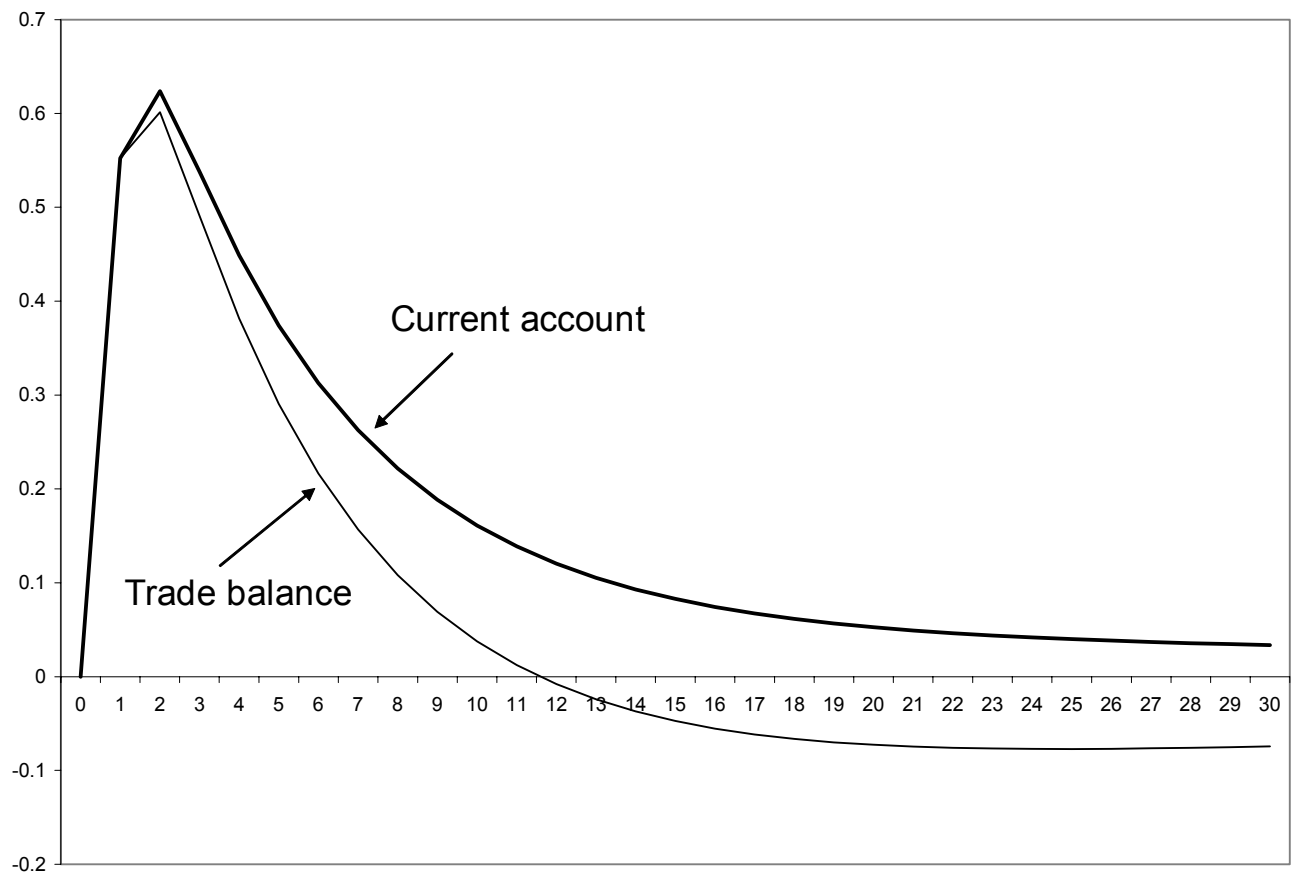

Figure 6. External balances in standard (FDF) model 


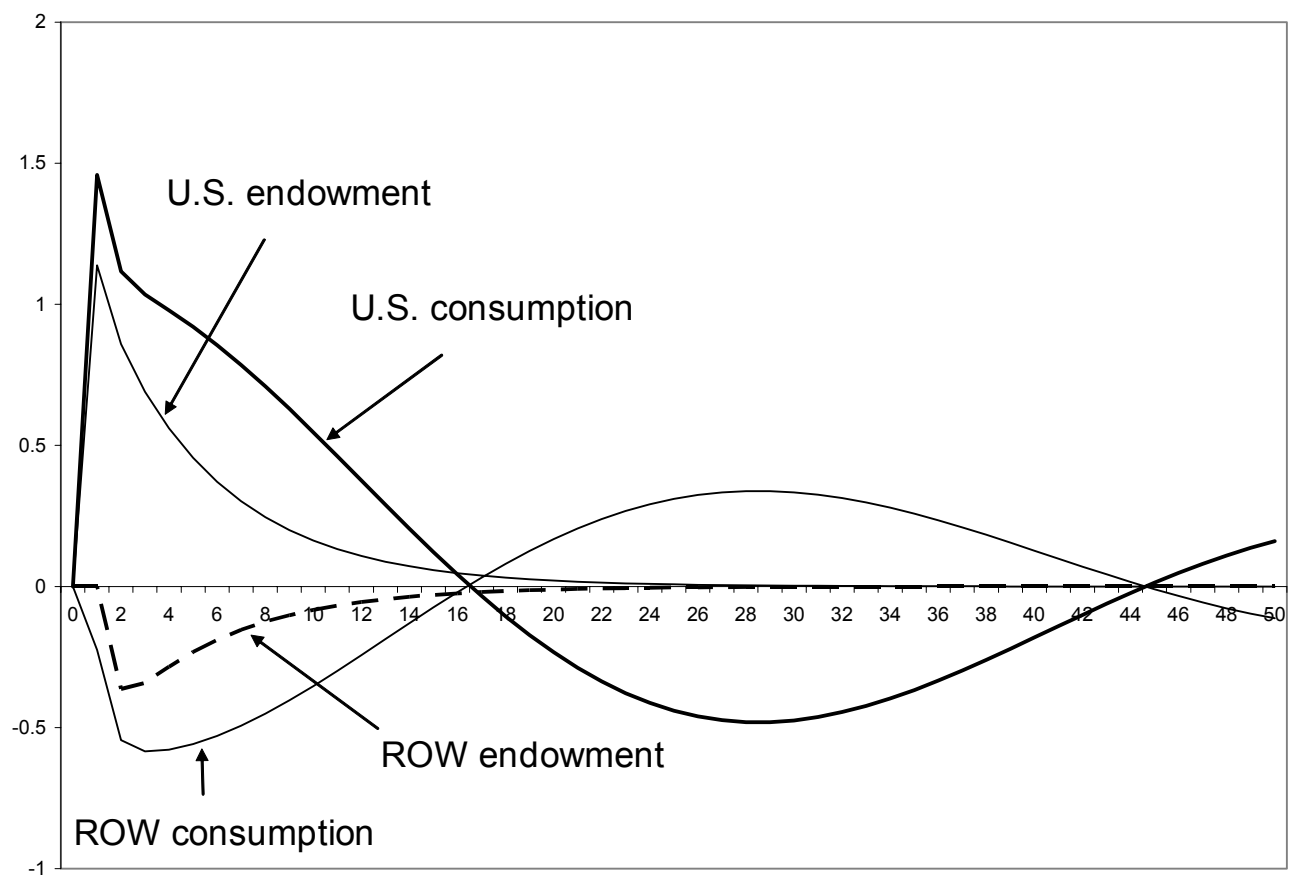

Figure 7: Consumption in endogenous discount model

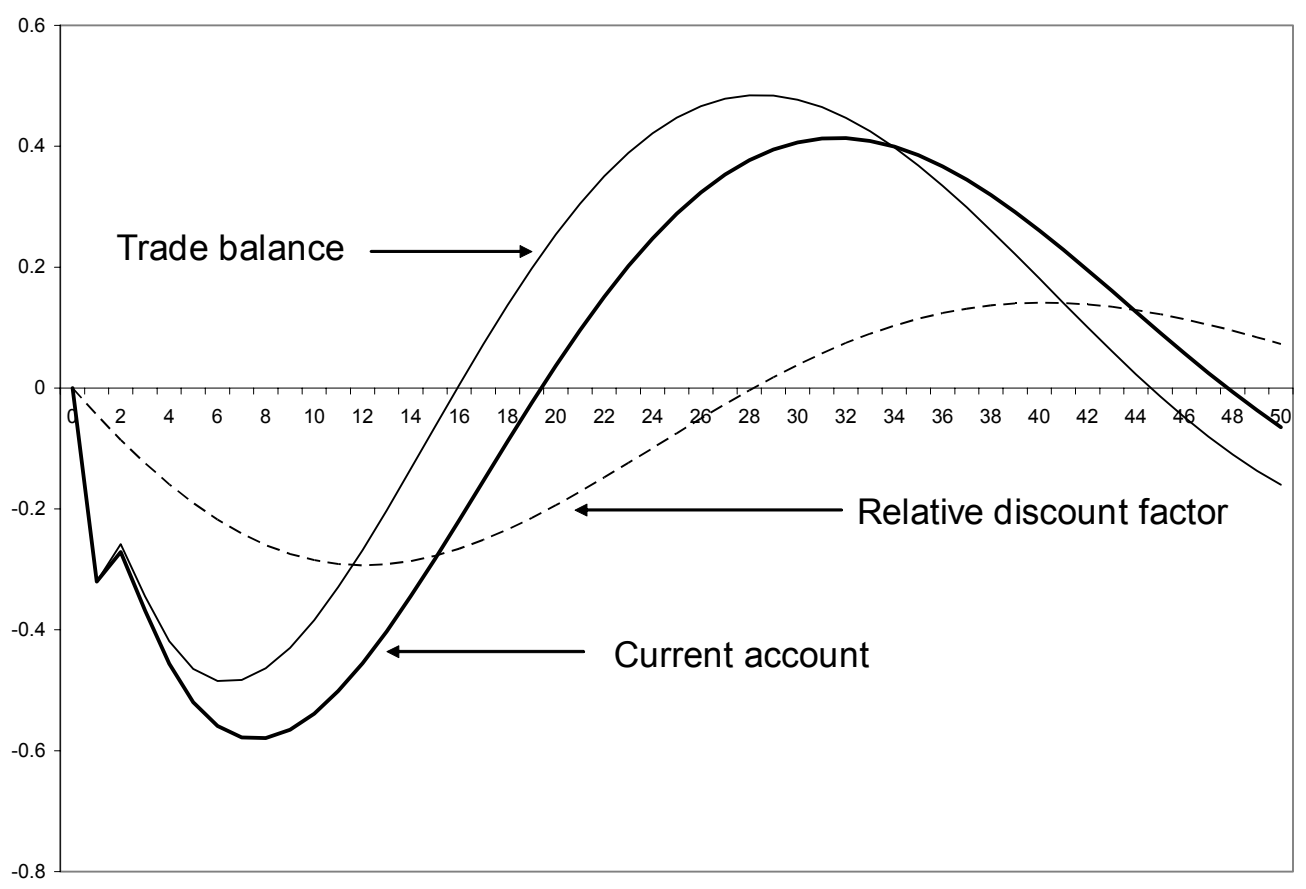

Figure 8: External balances in endogenous discount model 


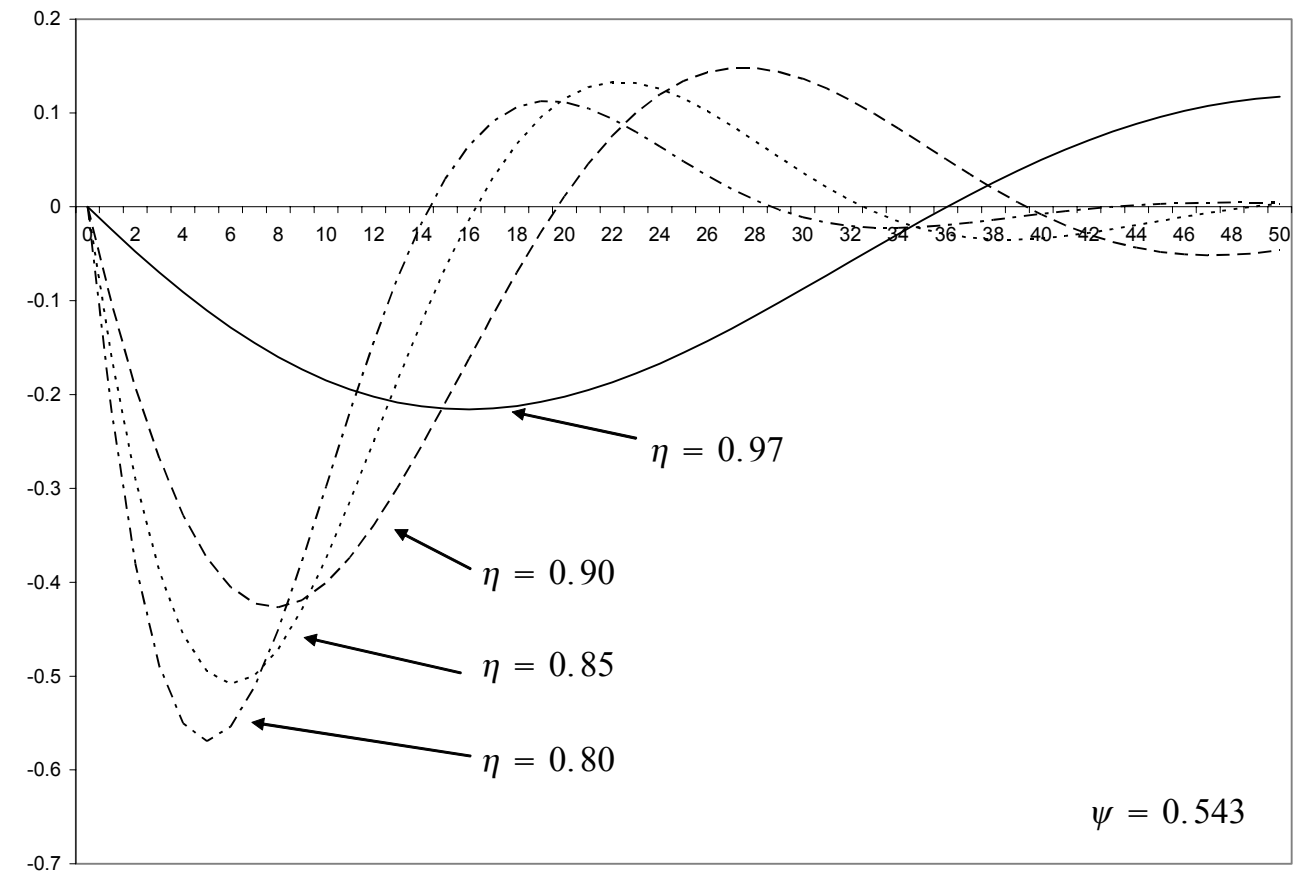

Figure 9. Sensitivity of relative discount factor with respect to $\eta$

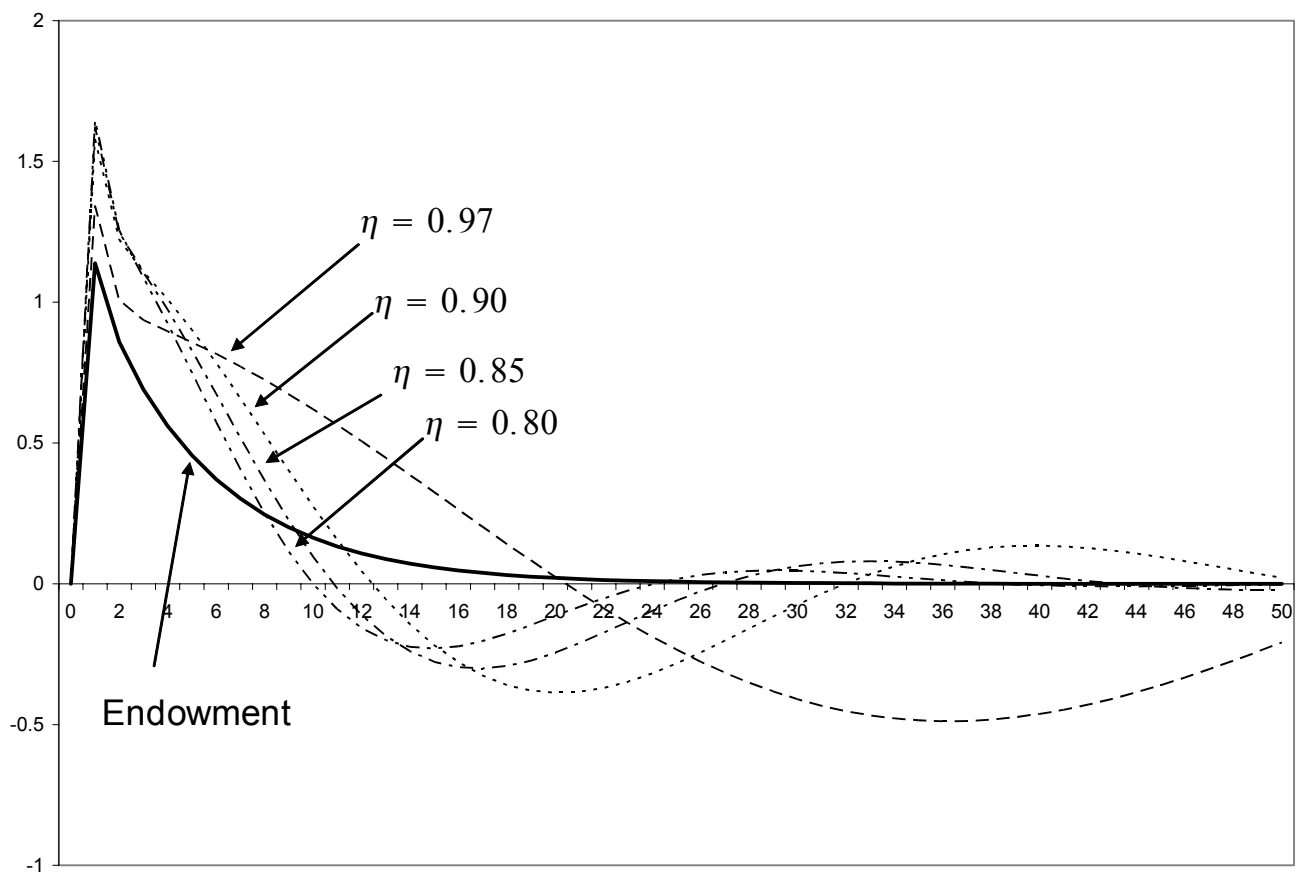

Figure 10: Sensitivity of USA consumption with respect to $\eta$ variations. 


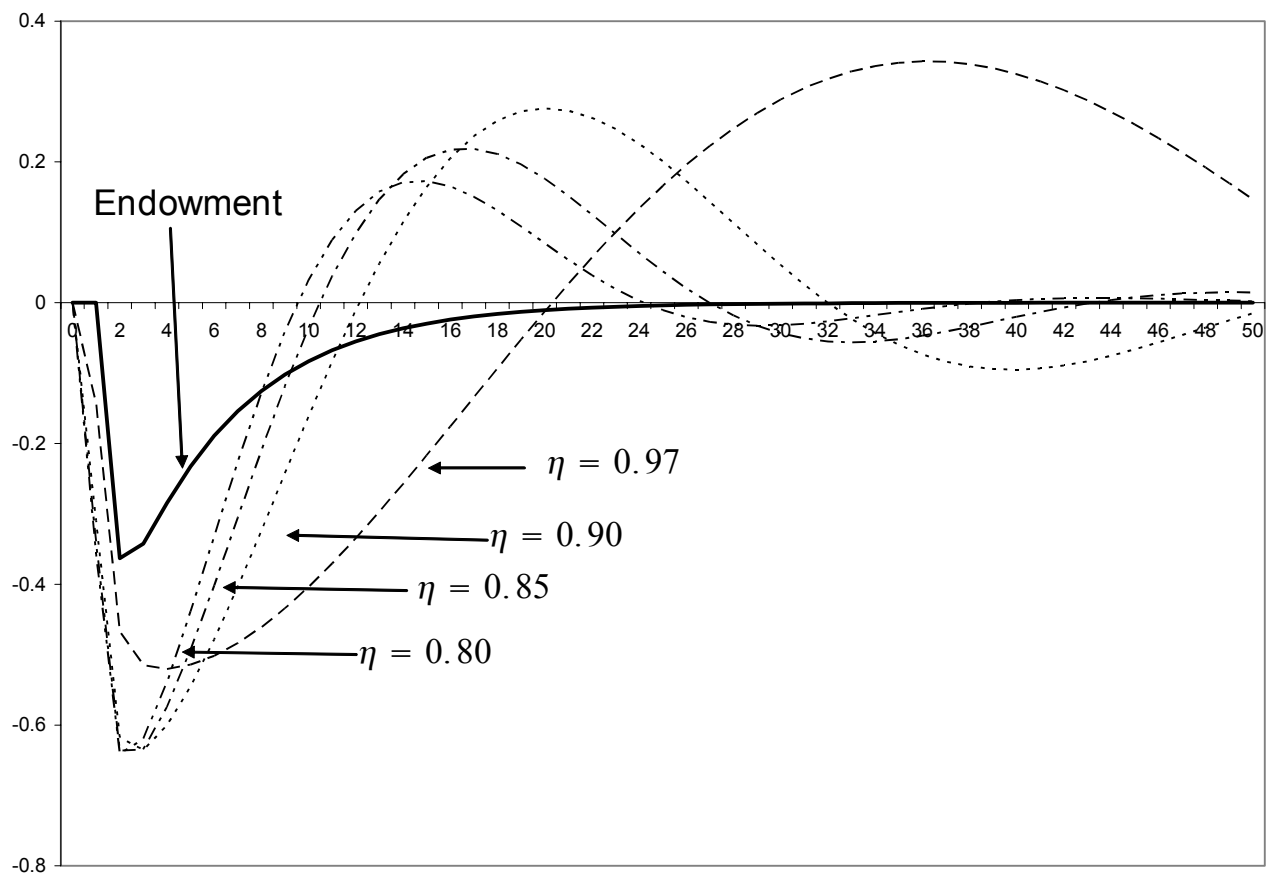

Figure 11: Sensitivity of ROW consumption with respect to $\eta$ variations

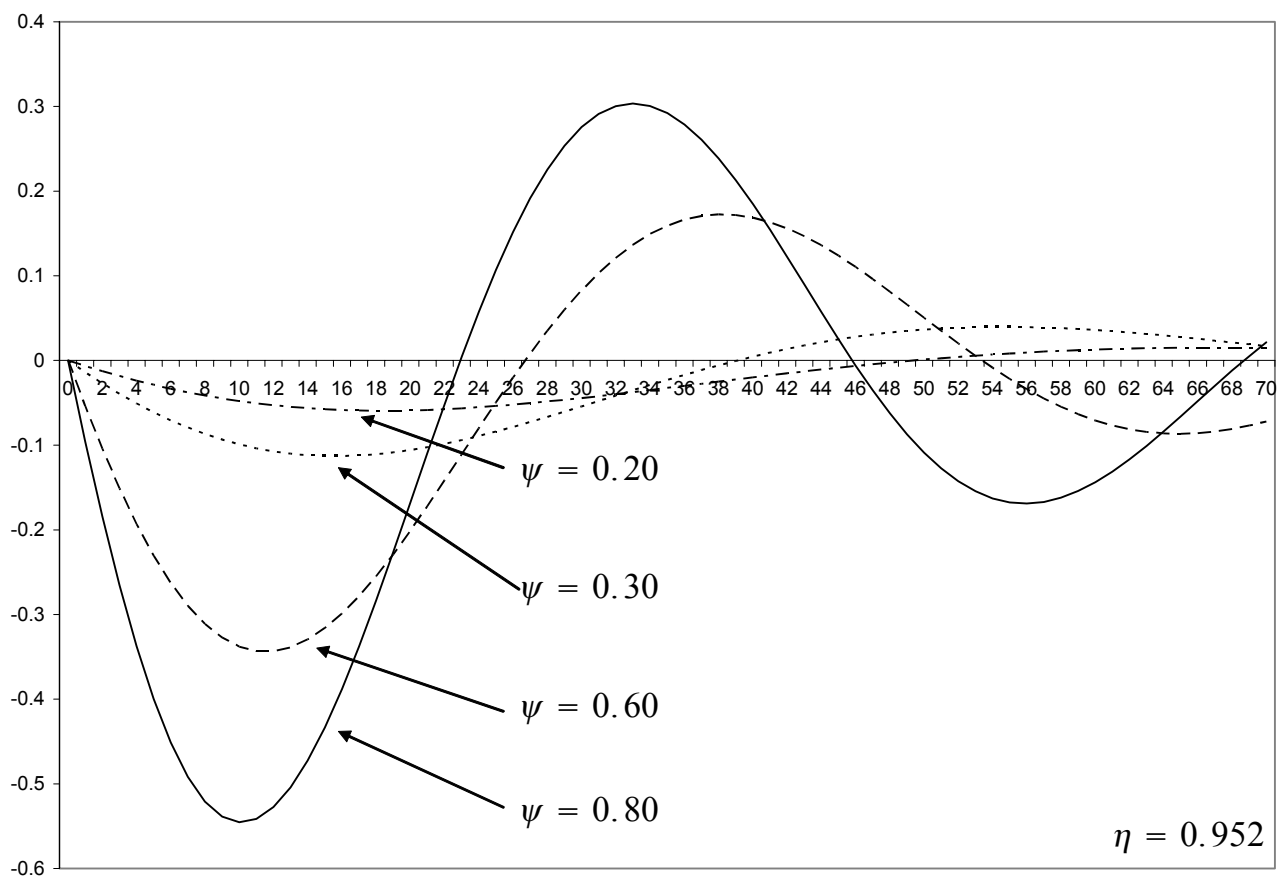

Figure 12. Relative discount factor sensitivity with respect to $\psi$ 


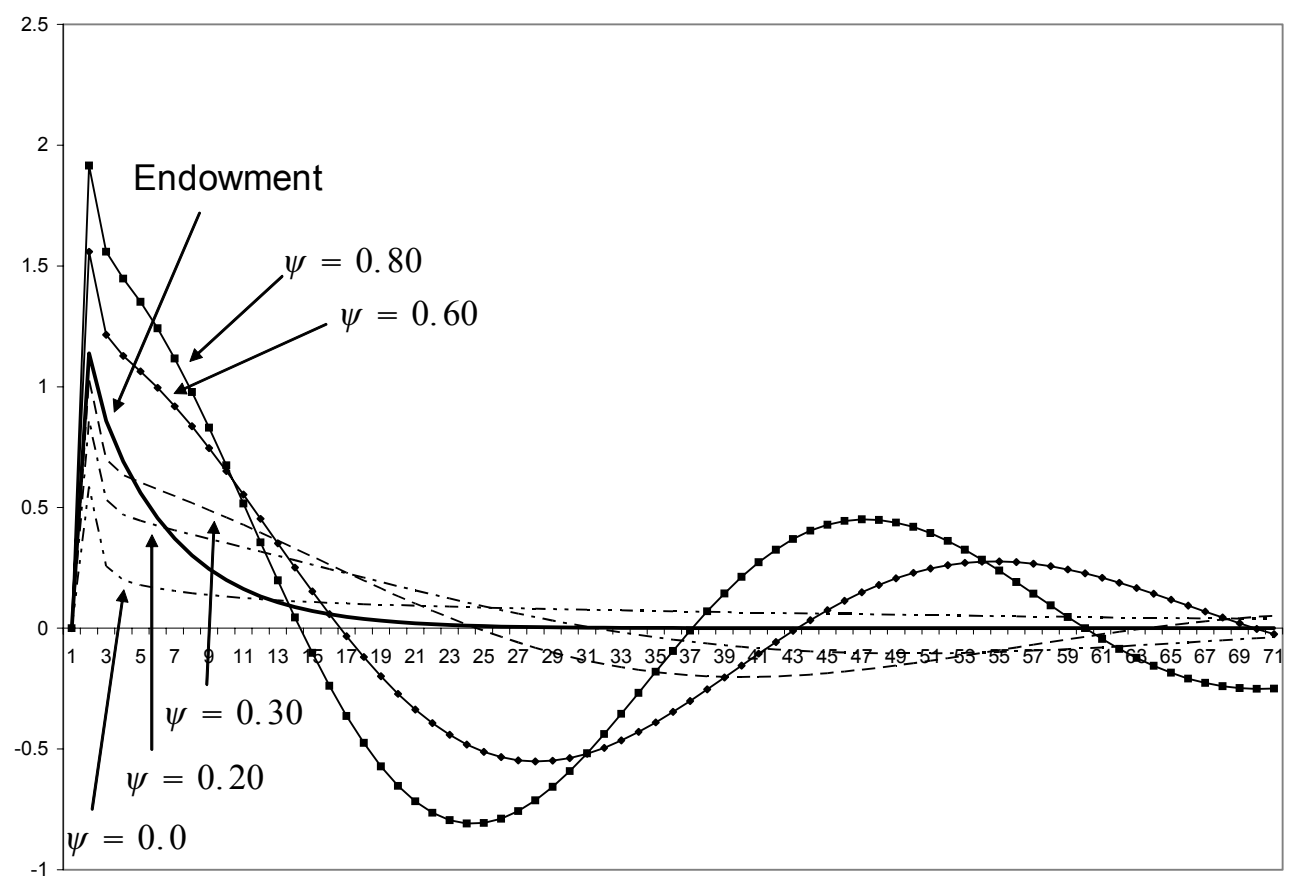

Figure 13: Sensitivity of U.S. consumption to variations in $\psi$

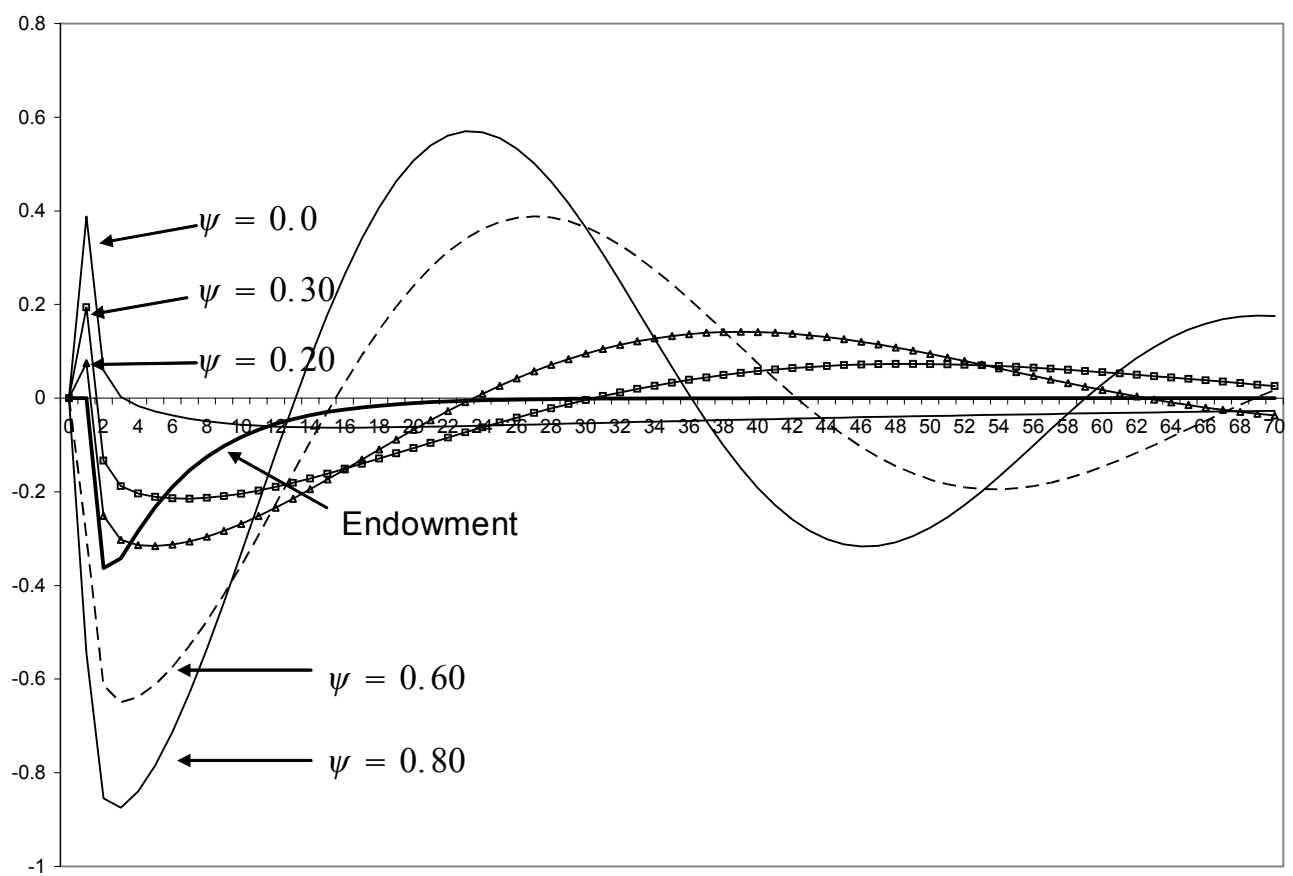

Figure 14: Sensitivity of ROW consumption to variations in $\psi$ 


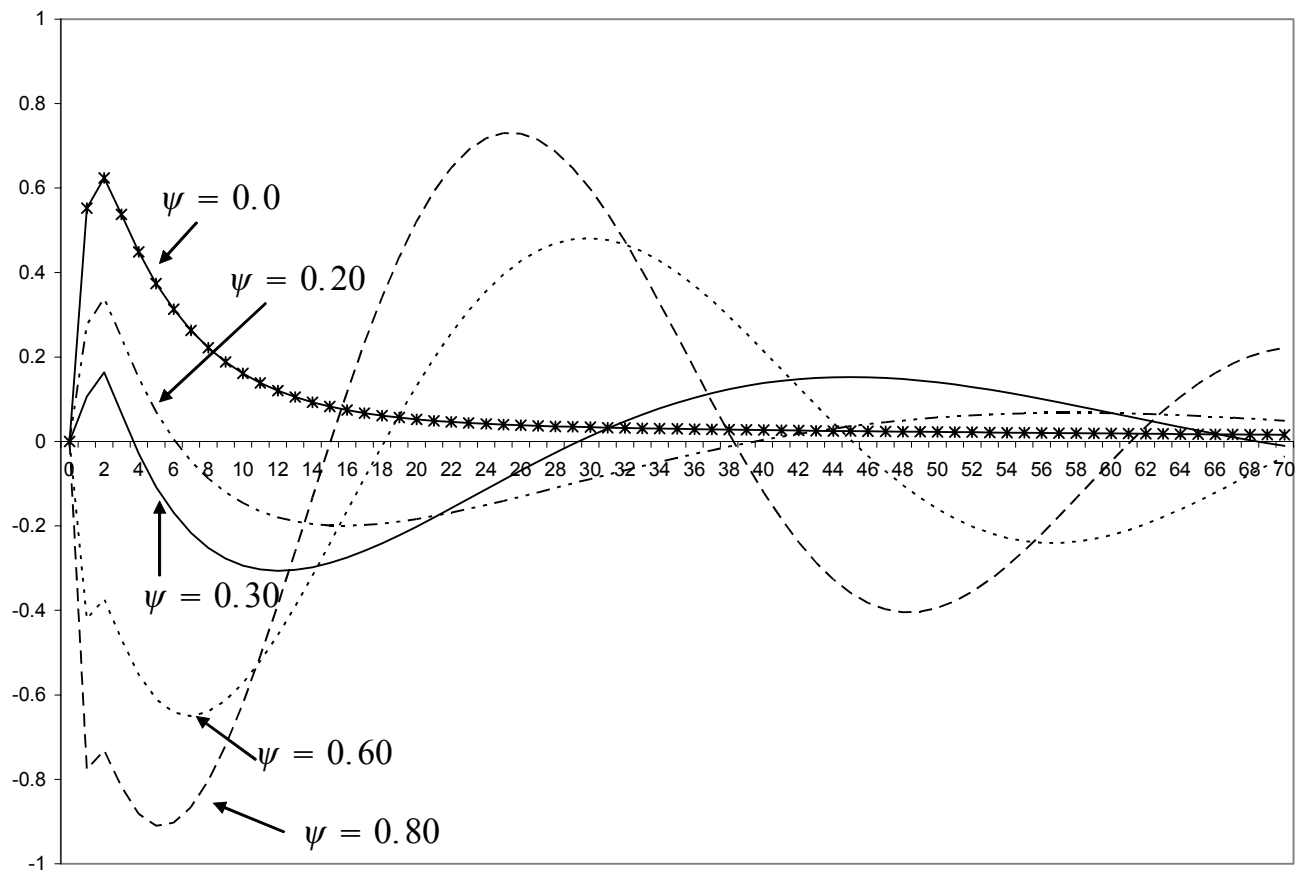

Figure 15. Sensitivity of current account to variations in $\psi$. 


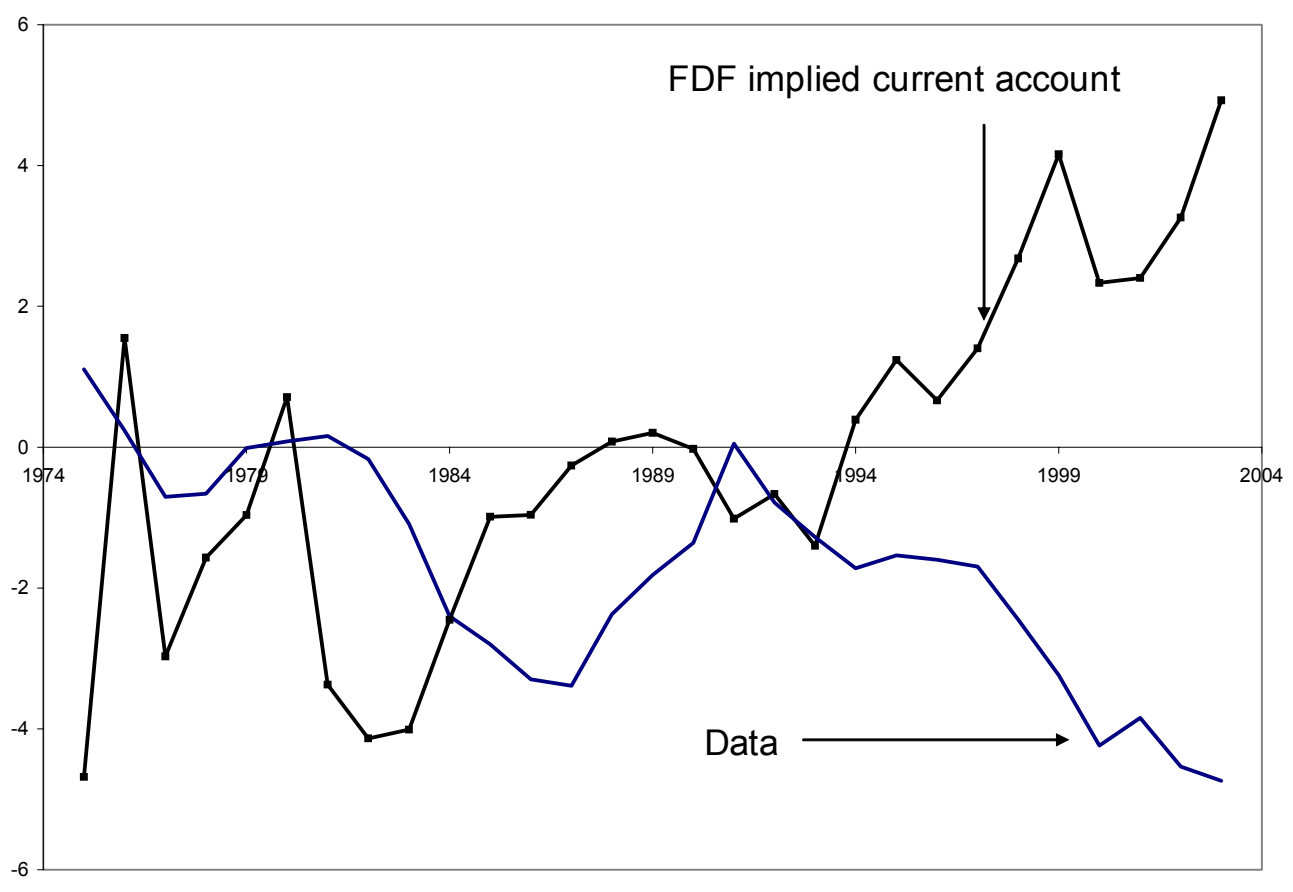

Figure 16: Predicted current account balances in the FDF model

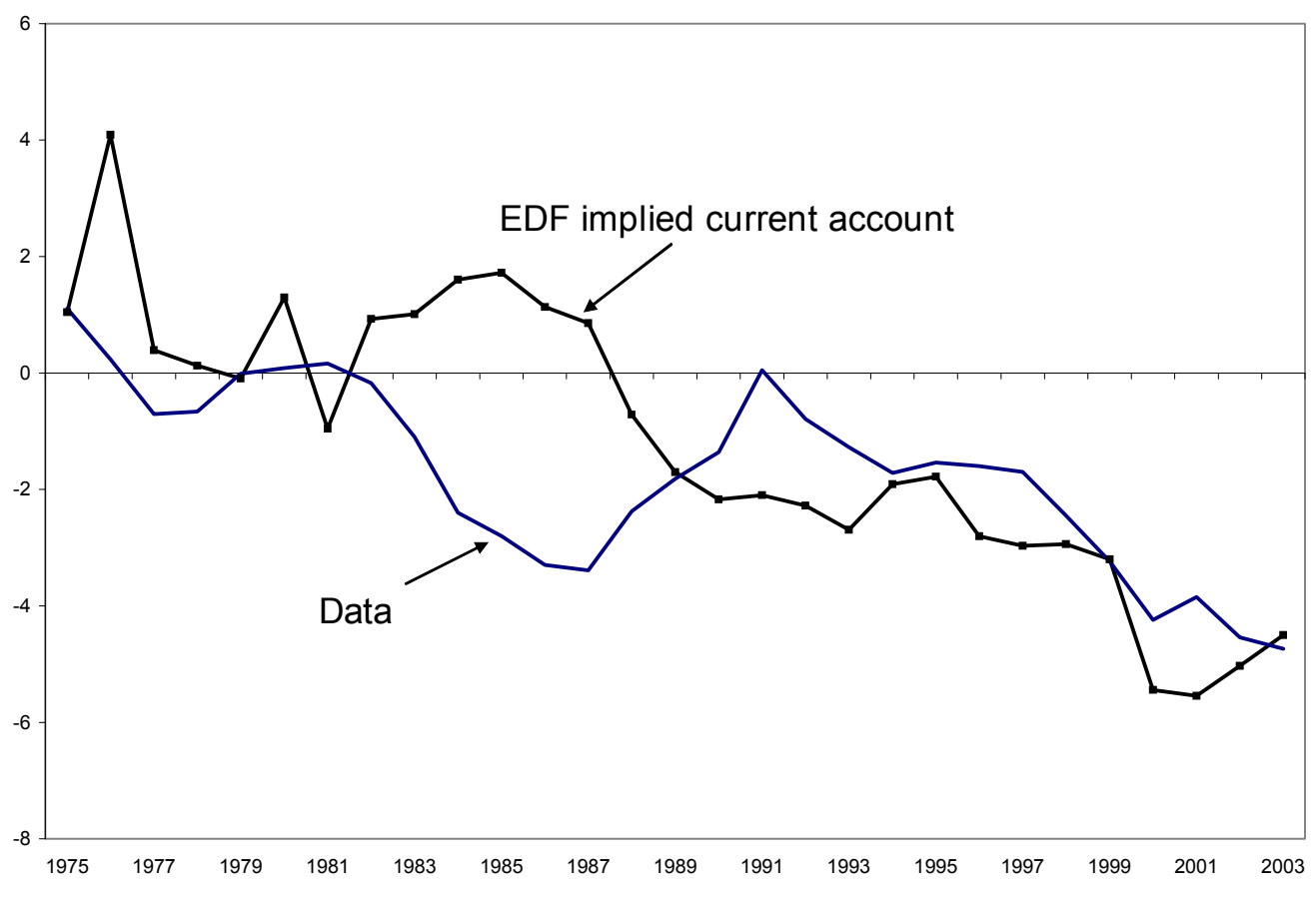

Figure 17: Predicted current account balances in the EDF 


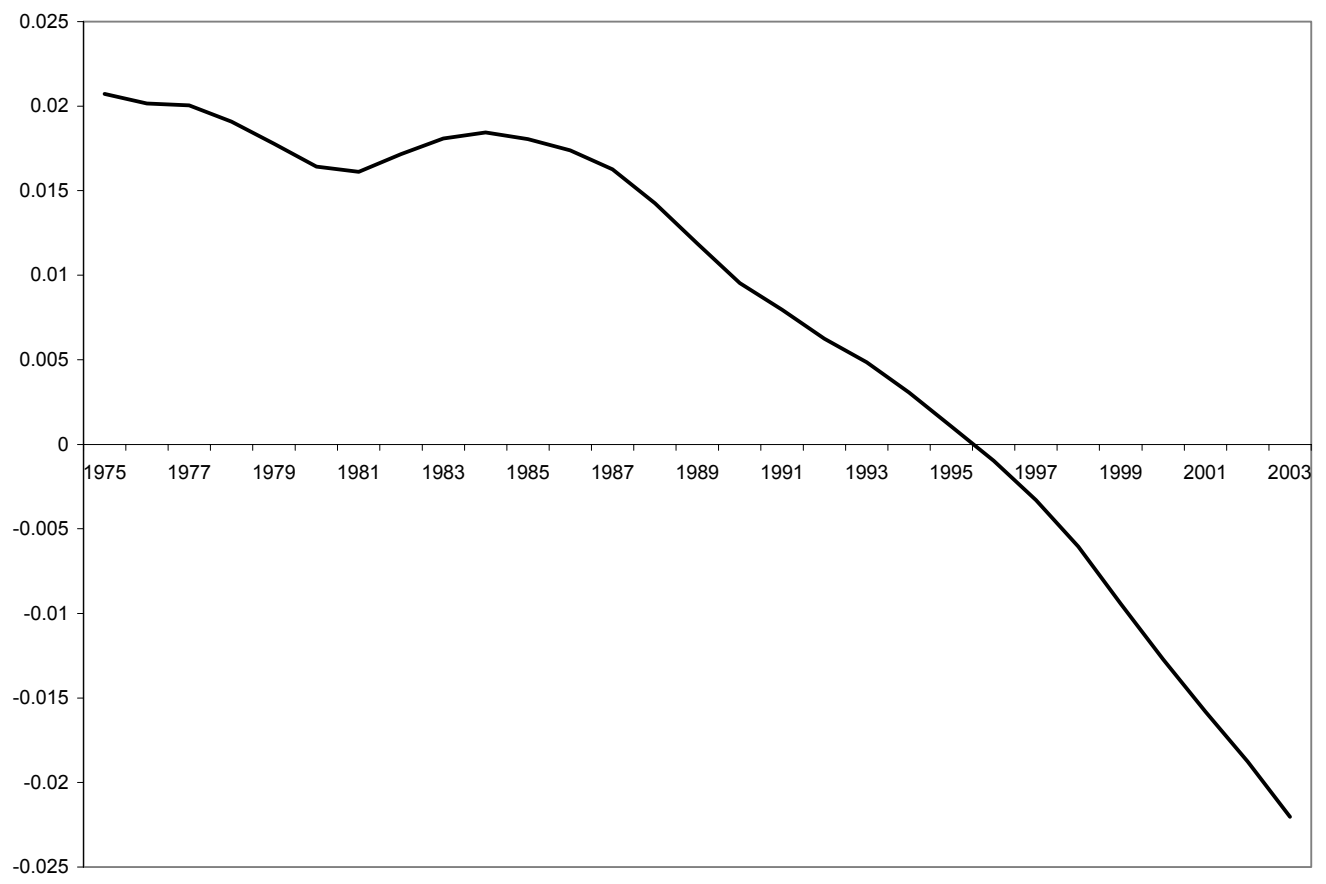

Figure 18: Predicted relative discount factor 


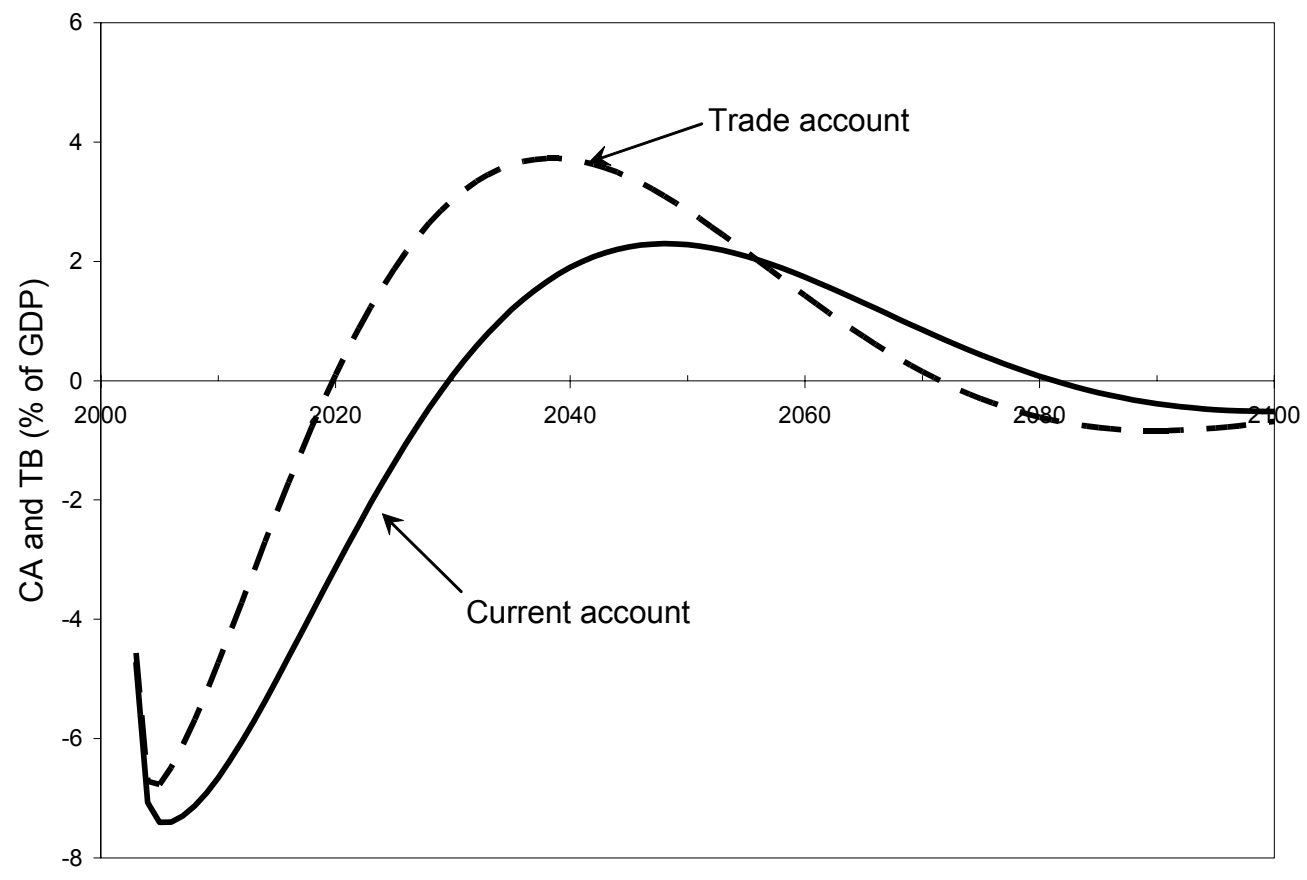

Figure 19: Projected external balances

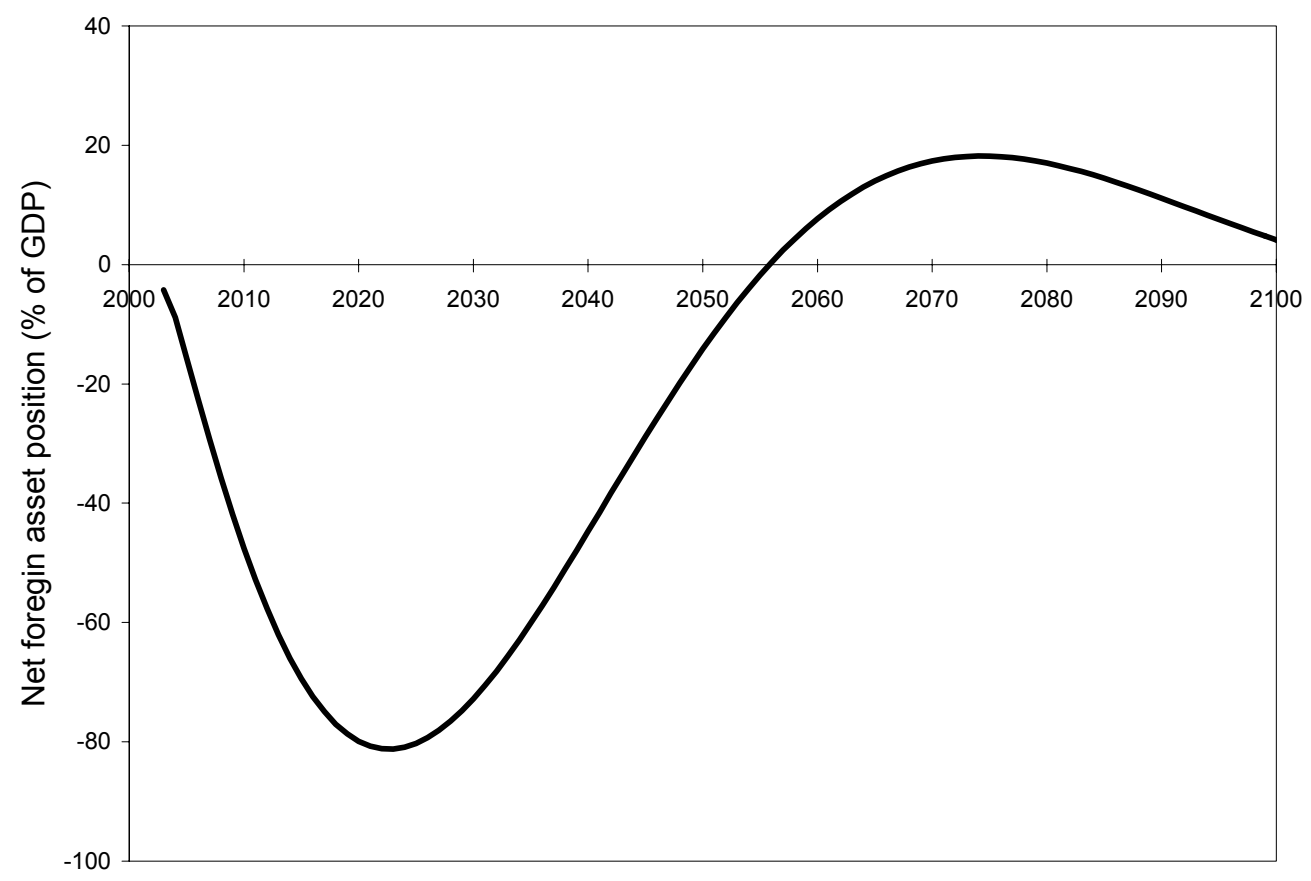

Figure 20: Projected net foreign asset position 


\section{Appendix}

\section{A.1 The Data}

The current account and trade account are from the U.S. national income and product accounts and are measured as the ratio of its nominal value to nominal GDP. The remaining data are all in real terms and obtained from the World Bank's World Development Indicators data set. The ROW is comprised of 23 high income OECD countries whose 2005 per capita gross national income exceeded $\$ 10,726$. The economies included are: Australia, Austria, Belgium, Canada, Denmark, Finland, France, Germany, Greece, Iceland, Ireland, Italy, Japan, Korea, Luxembourg, Netherlands, New Zealand, Norway, Portugal, Spain, Sweden, Switzerland and the United Kingdom.

GDP is measured at purchaser's prices, which is the sum of gross value added by all resident producers in the economy plus any product taxes and minus any subsidies not included in the value of the products. It is calculated without making deductions for depreciation of fabricated assets or for depletion and degradation of natural resources. As in Engel and Rogers (2006), ROW data are in constant 2000 U.S. dollars. Dollar figures for GDP are converted from domestic currencies using 2000 official exchange rates.

\section{A.2 The Model in Detrended Aggregates}

Here, we show how the model can be written down in terms of detrended aggregate variables. The exposition here includes the small bond market participation cost $\xi$ that is required to get international indebtedness to be stationary in the FDF.

Let variables detrended by the endowment trend with normalizations be $\widetilde{X}_{j, t}=X_{j, t} e^{-g t-\delta j}$. Then, the endowment follows

$$
\left(\begin{array}{l}
\ln \widetilde{Y}_{1, t} \\
\ln \widetilde{Y}_{2, t}
\end{array}\right)=\mathbf{A}\left(\begin{array}{c}
\ln \widetilde{Y}_{1, t-1} \\
\ln \widetilde{Y}_{2, t-1}
\end{array}\right)+\left(\begin{array}{c}
\varepsilon_{1, t} \\
\varepsilon_{2, t}
\end{array}\right) .
$$

The bond Euler equation can be rewritten as

$$
v_{t}\left(1+\frac{\xi v_{t} \widetilde{B}_{j, t}}{\widetilde{Y}_{j, t}}\right)=\widetilde{\beta}_{j, t} E_{t}\left(\frac{\widetilde{C}_{j, t+1}}{\widetilde{C}_{j, t}}\right)^{-\gamma},
$$

where $\widetilde{\beta}_{j, t}=\beta_{j, t} e^{\gamma(n-g)}$. The modified subjective discount factor $\widetilde{\theta}_{j, t}=\theta_{j, t} e^{\gamma(n-g) t}$, evolves 
over time according to

$$
\begin{aligned}
& \widetilde{\theta}_{j, t}=\widetilde{\theta}_{j, t-1} \widetilde{\beta}_{j, t}=\widetilde{\theta}_{j,-1} \prod_{i=0}^{t} \widetilde{\beta}_{1, t-i}, \\
& \widetilde{\beta}_{j, t}=\widetilde{\beta}_{j, t-1}^{\eta}\left[\left(\frac{\widetilde{C}_{j, t}}{\widetilde{C}_{j}}\right)^{-\psi} \widetilde{\beta}\right]^{(1-\eta)},
\end{aligned}
$$

where $\widetilde{\beta}=\beta e^{\gamma(n-g)}$. The zero-net supply constraint on bonds is given as,

$$
\widetilde{B}_{1, t}+M \widetilde{B}_{2, t}=0,
$$

where $M=e^{\delta_{2}-\delta_{1}}$ is the relative size of the ROW to the U.S. The resource constraint is,

$$
\widetilde{Y}_{1, t}+M \widetilde{Y}_{2, t}=\widetilde{C}_{1, t}+M \widetilde{C}_{2, t}+\frac{\xi}{2} \frac{\left(v_{t} \widetilde{B}_{1, t}\right)^{2}}{\widetilde{Y}_{1, t}}+\frac{\xi}{2} \frac{M\left(v_{t} \widetilde{B}_{2, t}\right)^{2}}{\widetilde{Y}_{2, t}} .
$$

The trade balance to GDP ratio and and the current account balance to GDP ratio can be rewritten as

$$
\begin{gathered}
t b_{t}=\frac{\widetilde{Y}_{1, t}-\widetilde{C}_{1, t}}{\widetilde{Y}_{1, t}} \\
c a_{t}=t b_{t}+\frac{e^{-g}\left(1-v_{t-1}\right) \widetilde{B}_{1, t-1}}{\widetilde{Y}_{1, t}} .
\end{gathered}
$$

Reduced Equations. We collect the set of equations that characterize the model as

$$
\begin{aligned}
v_{t}\left(1+\frac{\xi v_{t} \widetilde{B}_{j, t}}{\widetilde{Y}_{j, t}}\right) & =\widetilde{\beta}_{j, t} E_{t}\left(\frac{\widetilde{C}_{j, t+1}}{\widetilde{C}_{j, t}}\right)^{-\gamma} \\
\widetilde{\beta}_{j, t} & =\widetilde{\beta}_{j, t-1}^{\eta}\left[\left(\frac{\widetilde{C}_{j, t}}{\widetilde{C}_{j}}\right)^{-\psi} \widetilde{\beta}^{(1-\eta)},\right. \\
\widetilde{Y}_{1, t}+M \widetilde{Y}_{2, t} & =\widetilde{C}_{1, t}+M \widetilde{C}_{2, t}+\frac{\xi}{2} \frac{\left(v_{t} \widetilde{B}_{1, t}\right)^{2}}{\widetilde{Y}_{1, t}}+\frac{\xi}{2} \frac{M\left(v_{t} \frac{\widetilde{B}_{1, t}}{M}\right)^{2}}{\widetilde{Y}_{2, t}} \\
\widetilde{C}_{1, t}+v_{t} \widetilde{B}_{1, t}+\frac{\xi}{2} \frac{\left(v_{t} \widetilde{B}_{1, t}\right)^{2}}{\widetilde{Y}_{1, t}} & \leq \widetilde{Y}_{1, t}+e^{-g} \widetilde{B}_{1, t-1} \\
t b_{t} & =\frac{\widetilde{Y}_{1, t}-\widetilde{C}_{1, t}}{\widetilde{Y}_{1, t}}, \\
c a_{t} & =t b_{t}+\frac{e^{-g}\left(1-v_{t-1}\right) \widetilde{B}_{1, t-1}}{\widetilde{Y}_{1, t}} .
\end{aligned}
$$


Steady State. In the steady state, we have

$$
\widetilde{Y}_{1}=\widetilde{Y}_{2}=1, \quad \widetilde{B}_{1}=0, \quad \widetilde{\beta}_{1}=\widetilde{\beta}_{2}=\widetilde{\beta}
$$

It follows that

$$
\widetilde{C}_{1}=\widetilde{C}_{2}=1, \quad t b=c a=0 .
$$

Log Linearization. Let $\widehat{x}_{t}=\frac{\widetilde{x}_{t}-\widetilde{x}}{\widetilde{x}}$, deviation from its steady state level. Also, let $\widetilde{H}_{1, t}=$ $\widetilde{B}_{1, t} / \widetilde{Y}_{1}$, country 1 bond holdings to GDP ratio. The linearizations give

$$
\begin{aligned}
\widehat{v}_{t}+\xi v \widetilde{H}_{1, t} & =\widehat{\beta}_{1, t}-\gamma\left[E_{t}\left(\widehat{C}_{1, t+1}\right)-\widehat{C}_{1, t}\right] \\
\widehat{v}_{t}-\frac{\xi v}{M} \widetilde{H}_{1, t} & =\widehat{\beta}_{2, t}-\gamma\left[E_{t}\left(\widehat{C}_{2, t+1}\right)-\widehat{C}_{2, t}\right], \\
\widehat{\beta}_{1, t} & =\eta \widehat{\beta}_{1, t-1}-\psi(1-\eta) \widehat{C}_{1, t}, \\
\widehat{\beta}_{2, t} & =\eta \widehat{\beta}_{2, t-1}-\psi(1-\eta) \widehat{C}_{2, t}, \\
\widehat{Y}_{1, t}+M \widehat{Y}_{2, t} & =\widehat{C}_{1, t}+M \widehat{C}_{2, t}, \\
\widehat{C}_{1, t}+v \widetilde{B}_{1, t} & \leq \widehat{Y}_{1, t}+e^{-g} \widetilde{H}_{1, t-1}, \\
t b_{t} & =\widehat{Y}_{1, t}-\widehat{C}_{1, t} \\
c a_{t} & =t b_{t}+e^{-g}(1-v) \widetilde{H}_{1, t-1} .
\end{aligned}
$$

We can combine first 4 equations as

$$
\begin{aligned}
\frac{(M+1) \xi v}{M} \widetilde{H}_{1, t} & =\widehat{\beta}_{t}^{*}-\gamma\left[E_{t}\left(\widehat{C}_{1, t+1}\right)-\widehat{C}_{1, t}\right]+\gamma\left[E_{t}\left(\widehat{C}_{2, t+1}\right)-\widehat{C}_{2, t}\right] \\
\widehat{\beta}_{t}^{*} & =\eta \widehat{\beta}_{1, t-1}^{*}-\psi(1-\eta)\left(\widehat{C}_{1, t}-\widehat{C}_{2, t}\right)
\end{aligned}
$$

where $\widehat{\beta}_{t}^{*}=\widehat{\beta}_{1, t}-\widehat{\beta}_{2, t}$. 